EstAg 32 (1997) 27-69

\title{
Una, eadem et vera. La Iglesia de Cristo en los comentarios impresos de Pedro de Aragón (1584)
}

En 1584 editaba en Salamanca el agustino Pedro de Aragón ${ }^{1}$ sus comentarios a la Secunda Secundae de Santo Tomás de Aquino ${ }^{2}$. También ese mismo año aparecían en Salamanca los de Domingo Báñez sobre la misma materia ${ }^{3}$. El erudito Franz Ehrle ${ }^{4}$ aludió a esta circunstancia cuando se refie-

1. Nació Pedro de Aragón en Salamanca (1545/1546). Profesó el 20 de septiembre de 1561 en el convento de San Agustín de la misma ciudad, donde estudió Artes. La Teología la cursó en la Universidad desde 1564 hasta 1568. Pasó luego a Huesca. Allí obtuvo el título de maestro de Teología (1573). Más tarde incorpora en Salamanca los títulos de licenciado y de maestro (1576). Comienza su docencia salmantina desde la cátedra de Escoto (1576-1582) y pasa después a la de Súmulas (1582-1592). A ambas había accedido por oposición. En 1582 intentó el acceso a la cátedra de Durando; pero se lo impidió el dominico Juan Vicente. Murió en 1592.

Biografía, cf.: V. OBLET, "Aragón, Pierre", en Dictionnaire de Théologie Catholique 1 (París 1909) 1728-1729; E. D. CARreTero, “Aragón, Pedro de", en Diccionario de Historia Eclesiástica de España 1 (Madrid 1972) 77; J. BARRIENTOS GARCÍA, "La justicia en la distribución de los cargos públicos y cargas o impuestos en Pedro de Aragón", en La Ciudad de Dios 206 (1993) 299-300.

2. El título completo de la obra reza así: "Fratris Petri de Aragon, ordinis eremitarum sancti Augustini, artium et sacrae Theologiae magistri, et in clarissima Salmanticensi Academia publici professoris. In secundam secundae Diui Thomae Doctoris Angelici commentariorum. Tomus Primus. Salmanticae. Excudebat Ioannes Ferdinandus MDLXXXIIII".

Esta obra se citará siempre en referencia al comentario al artículo décimo de la cuestión primera. Al haber dos columnas en la obra editada, la letra que acompañará al número de página indicará si se trata de la primera de ellas $a$ o de la segunda $b$.

3. D. BÁÑEZ, Scholastica commentaria in Secundam Secundae angelici doctoris $S$. Thomae (q. 1-q. 46), Salmanticae 1584.

4. "Habiendo llegado a su conocimiento que el agustino Pedro de Aragón preparaba para la imprenta un comentario a la 2a. 2ae., en el cual temía Báñez que se sirviera de materiales pertenecientes a sus predecesores en el cargo, empezó también al mismo tiempo la publicación de esta parte de la Suma. Por eso aparecieron simultáneamente en 1584, en Salamanca, dos extensos comentarios a la primera parte de la $2 \mathrm{a}$. 2ae. (de fide, spe et caritate) de los cuales uno contenía los trabajos del dominico de San Esteban y el otro los del agustino de San Agustín". F. EHRLE (J.M. MARCH), "Los manuscritos vaticanos de los teólogos salmantinos del siglo XVI. De Vitoria a Báñez", en Estudios Eclesiásticos 9 (1930) 162. 
re a la noticia del dominico sobre la posible publicación que se planeaba en el convento de los agustinos. Báñez llevaba al parecer algún retraso en la confección de su obra. ¿Tenía acaso miedo éste de que Aragón utilizara en sus comentarios a la Secunda Secundae exposiciones doctrinales de los dominicios? Fue precisamente el año 1526 cuando Francisco de Vitoria comenzó a explicar la Secunda Secundae de Santo Tomás desde la cátedra de Prima de la Universidad de Salamanca. Sus comentarios no fueron dados a la imprenta para ser publicados. Diversos fueron los profesores posteriores que continuaron comentando desde sus cátedras la Suma Teológica del Aquinate. Tampoco entregaron los mismos a imprenta alguna. Hubieron de pasar 58 años hasta que todos aquellos comentarios expuestos en Salamanca cristalizaran en una edición de imprenta. Aparecieron los mismos en dos libros diversos: los de Aragón y Báñez. Este hecho significaba a las claras la terminación de una etapa. Se había puesto fin a unos años de intenso trabajo de investigación y de acomodación. Había llegado el tiempo de poder ofrecer abiertamente la exposición adecuada y completa de los comentarios salmantinos sobre la Secunda Secundae de Santo Tomás.

Recibe el nombre de Escuela de Salamanca ${ }^{5}$ aquel movimiento iniciado por Vitoria con su entrada en la Universidad de esta ciudad el año 1526 y decidió ajustar sus comentarios a la Suma Teológica del Aquinate. No quiso atenerse a la explicación de los Cuatro Libros de las Sentencias de Pedro Lombardo. Es cierto que la mayor parte de los profesores salmantinos de Prima y de Vísperas ${ }^{6}$ del siglo XVI pertenecían a los dominicos; pero, ¿queda reducida la Escuela de Salamanca por ello a autores de una sola orden religiosa? En su obra sobre el Papa, el concilio y la infalibilidad, Ulrich Horst no habla de Escuela de' Salamanca. Prefiere mencionar las escuelas de los dominicos, de los agustinos y de los jesuitas ${ }^{7}$. Quien escribe ha preferido en todos los trabajos considerar miembro de la Escuela de Salamanca del siglo XVI a quien comenta la Suma de Santo Tomás y es profesor de la Universidad salmantina. A este respecto considera carente de importancia que el profesor lo

5. Sobre la expresión Escuela de Salamanca, cf.: C. Pozo, "Salmantizenser", en Lexikon für Theologie und Kirche 9 (Freiburg im Breisgau 1964 (268-269; L. MARTíNEZ FERNÁNDEZ, La teoría del progreso dogmático en los reportata inéditos de Juan de Guevara (Vitoria 1967) 47-64; I. JERICO, De Articulus fidei hacia Dogma fidei. La doctrina y la verdad de fe católicas en la Escuela de Salamanca (1526-1584), (Vitoria 1981) 1-5.

6. Eran las dos cátedras principales de la Universidad. El profesor estaba obligado a atenerse en su explicación a la doctrina común. Las cuestiones de corriente se trataban en las cátedras menores. Recibían estas cátedras el nombre de Prima y de Vísperas por iniciarse las mismas cuando se comenzaba el rezo de dichas horas canónicas en la catedral.

7. Cf.: U. Horst, Papst-Konzil-Unfehlbarkeit. Die Ekklesiologie des Summen-kommentare von Cajetan bis Billuart (Mainz 1978) 64, 143 y 162. 
haga desde una cátedra mayor o menor ${ }^{8}$. Salta a la vista que dos comentarios sobre la misma materia y publicados el mismo año no se resisten a la comparación y al juicio contrastado. U. Horst decía al respecto que, mientras el trabajo de Báñez conquistó con toda rapidez una categoría especial, no sucedió lo mismo con el del agustino. De todas formas, reconoce este dominico alemán que no es pérdida de tiempo alguna reflexionar con un detenimiento mayor sobre la Eclesiología de Pedro de Aragón por hallarse en ella una serie de interesantes matizaciones ${ }^{9}$.

U. Horst reconoce abiertamente la existencia de matizaciones de interés en la eclesiología de Pedro de Aragón. Está fuera de toda duda que la Escuela de Salamanca del siglo XVI contribuyó decisivamente a la aparición y consolidación del moderno tratado teológico "De Ecclesia" ${ }^{10}$. La eclesiología se gestó en la Escuela de Salamanca con ocasión del comentario al artículo décimo de la cuestión primera de la Secunda Secundae. La Suma Teológica del Aquinate ofrecía a los salmantinos la posibilidad de hablar concretamente de la Iglesia. Se preguntaba el artículo mencionado si pertenecía en último término al Sumo Pontífice la ordenación del símbolo. En un primer momento, los salmantinos se aprestaron a tratar sobre el poder y la autoridad de la Iglesia: el concilio general y el Papa. En un segundo momento, caen en la cuenta además de cómo la fe no es solamente propuesta y que había mucho tenido como de fe en la Iglesia que vive en el sentir de los cristianos sin necesidad de ser propuesto desde la autoridad. Esta constatación llevó a fijar la atención de los teólogos en la realidad de la Iglesia, la cual no quedaba reducida al concilio general en armonía con el Sumo Pontífice. Se tomó más que nunca en consideración que todos los fieles eran Iglesia de verdad. Se sintió entonces la necesidad de precisar qué es y dónde se halla la Iglesia de Cristo.

Aquí no se afrontarán las cuestiones de la infalibilidad de los concilios y del Sumo Pontífice en la definición de la fe. Tampoco se ofrecerá la exposición de Aragón sobre la Sagrada Escritura y las tradiciones apostólicas para probar los dogmas de fe. Pese a su interés, no se expondrá las cuestiones de si los herejes pertenecen a la Iglesia o de si los pecadores son miembros de

8. Cf.: I. JERICÓ, De Articulus fidei hacia Dogma fidei. El camino entre la doctrina y verdad de fe católicas en la Escuela de Salamanca (1526-1584), (Vitoria 1981) 1-4.

9. "In Jahre 1584 erschienen nun zwei umfangreiche Kommentare zur Secunda Secundae im Druck, die dem Augustiner Petrus de Aragón und Dominicus Báñez zu verfassern hatten. Auch wenn das Werk des Dominikaners schon rasch einen besonderen Rang einnahm, lohnt es sich, die Ekklesiologie des Petrus de Aragón näher zu betrachten, zumal sich in ihr eine reihe von interessanten Nuancierungen finden". U. HoRST, Papst-Konzil-Unfehlbarkeit. Die Ekklesiologie der Summenkommentare von Cajetan bis Billuart, (Mainz 1978) 149-150.

10. Cf.: I. JERICó, "El moderno tratado De Ecclesia y sus inicios en la Escuela de Salamanca", en Communio 28 (1995) 3-46. 
ella de verdad. De todas formas, es necesario indicar aquí que Pedro de Aragón considera a los herejes fuera de la Iglesia y llama a los pecadores miembros verdaderos de ella. La Iglesia es ante todo congregación de los que tienen fe. Asimismo, no se dirá nada en este estudio sobre la problemática del Papa caído en herejía. ¿Qué es entonces lo que se ofrecerá en el mismo? Se enumerarán las notas de la Iglesia de Cristo y se tratará de verificar cómo las mismas se cumplen únicamente en la Iglesia de Roma. El origen de la Iglesia no se halla en Cristo; se remonta al menos hasta Abel. La Iglesia verdadera existió antes de haber Escritura alguna. En la Iglesia, además de la fe, es necesario hacer confesión externa de la misma. Siempre ha habido y habrá fe y gracia de verdad en la Iglesia de Cristo ${ }^{11}$.

Dos partes abarcará el presente trabajo. La primera se dedicará a exponer la doctrina de Aragón tal y como él la escribió. La segunda tratará de exponer el marco y el desarrollo de los comentarios dentro de la teología.

\section{PRIMERA PARTE}

El término latino ecclesia viene del griego. Lo utilizan los escritores sagrados y profanos cuando hacen referencia a la reunión que ha sido convocada. Designa este término así el encuentro y la reunión de las personas congregadas en una unidad gracias a la voz y al mandato de una persona. Ecclesia se diferencia del término sinagoga. Según San Agustín, se aludía con este nombre a cualquier congregación sin especificarse si se trataba de hombres o de reses. Se habla de congregación de reses en el evangelio de San Mateo. También se señala en el mismo (Mt 23,37) ${ }^{12}$ cómo la gallina reúne a sus pollos. Iglesia designa sólo la congregación de seres racionales. Éstos son a su

11. El campo de la investigación presente queda resumido perfectamente en esta frase sobre la Iglesia en general referida a los comentarios de P. de Aragón:

"Die Kirche als sichtbare Gemeinschaft hat ihren Ursprung in Abel, aber als congregatio fidelium, die den Glauben an Christus bekennt und sich der von ihm gestiften Zeichen bedient, nimmt sie den Anfang mit der Passion des Herrn. Sie wird auch die Zeiten überdauern; ihre Existenz hört nicht auf, sie lebt stets in einer grösseren Gruppe von Gläubigen weiter. Ihre konkrete Realisierung findet sie bei den Gläubigen, die den römischen Papst als Nachfolger Petri und Vikar Christi anerkennen. Die römische Kirche allein ist firma, inviolabilis et inconcussa geblieben. Nur sie besizt die schriftliche und mündliche Lehre der Apostel, auch hat sie allein die rechtmässige bischöfliche Sukzession". U. HORST, Papst-Konzil-Unfehlbarkeit. Die Ekklesiologie der Summenkommentare von Kajetan bis Billuart (Mainz 1978) 151-152.

12. Aunque lo normal es colocar la sigla Cf. en las citas bíblicas cuando las mismas no son textuales, a lo largo de todo este trabajo se citará la Biblia de modo no textual y no se hará uso de la sigla citada. 
vez los que pueden ser convocados ${ }^{13}$. A veces, se designa con tal término el lugar preciso en el que se juntan las personas. Así es como suele hablarse de iglesias cundo se quiere hacer referencia a los templos. Esta significación no se halla por otra parte muy alejada de las Sagradas Escrituras. El libro de Judit $(6,20)$ habla de cómo se reunió todo el pueblo y de cómo se hizo adoración durante toda la noche en la iglesia. Es ésta una significación que se halla también en Luciano. Invita Aragón a consultar las exposiciones al respecto de Alfonso de Castro, Francisco de Vitoria, Melchor Cano, Johann Driedo, Albert Pigge y Juan de Torquemada ${ }^{14}$.

La Iglesia suele entenderse en toda su amplitud cuando abarca la congregación de los hombres todos sin distinguir a buenos y malos, a fieles o infieles. Así es como usa el término el Salmo $(25,5)$ al referirse a la iglesia de los malvados. Pero este nombre de iglesia de los malvados se toma solamente en este lugar para significar la congregación de aquéllos que se alejan del camino de Cristo y de la religión verdadera. Se limita en consecuencia su uso a la llamada por los escritores sagrados como la iglesia de Satanás o la ciudad de Babilonia. Tal congregación surgió al mismo tiempo que la Iglesia de Cristo; crece a su lado y ha de perseverar además hasta el fin del mundo ${ }^{15}$.

A la Iglesia, a la que se hace referencia en este lugar, cabe definirla como la multitud de fieles que coinciden en la fe y en el culto del único Dios en

13. "Tractatus de Ecclesia. Et vt a nomine ipso exordiamur, aduertendum est primo, quod Ecclesia est nomen Graecum saepe ab scriptoribus, tam sacris, quam prophanis vsurpatum, significatque Latine conuocatam contionem, id est, coetum et congregationem hominum, alicuius voce atque imperio in vnum conuenientium. Et differt a Synagoga, vt autor est D. August. super psal. 77. et 78. in eo, quod Synagoga, quod etiam est nomen Graecum, significat simpliciter quamcumque congregationem, siue hominum, siue pecudum: nam etiam pecora congregari dicuntur, iuxta illud Mat. 23. Gallina congregat pullos suos. At vero Ecclesia tantum significat congregationem eorum, qui ratione vtuntur: hi enim solum sunt, qui conuocari possunt". 50a-50b.

14. "Accipitur etiam Ecclesia interdum pro loco ipso, in quo homines congregantur, vnde ipsa templa Ecclesias appellare solemus: estque ista significatio non multum aliena a sacris literis, nam Iudith c. 6. dicitur, Conuocatus est omnis populus, et per totam noctem intra Ecclesiam orauerunt. Similiter Lucianus accepit Ecclesiam in hac significatione in multis locis suorum dialogorum. De hac re videndus est Castro lib. 6. de Haeres. verbo Ecclesia, et lib. 1. cap. 6. Et Victoria in relectione de potestate Ecclesiastica, in principio, et Cano de locis lib. 4. c. 2. et Driedo lib. 4. de Ecclesiasticis dogmatibus c. 2. et Albertus Campensis, lib. 1. de Ecclesiastica Hierarchia, cap. 1. et Turrecremata lib. 1. suae sum. c. 1.". 50b.

15. "Secundo aduertendum, quod licet Ecclesia secundum totam suam latitudinem accipiatur pro quacumque hominum congregatione, siue bonorum siue malorum, siue fidelium siue infidelium, vt constat ex illo psalm. 25. (texto: 21.) Odiui Ecclesiam malignatium: tamen nos in praesenti tantum accipimus hoc nomen, in quantum significat congregationem hominum aberrantium a Christo, et a vera religione, quae a sacris scriptoribus appellatur Ecclesia Sathanae, seu ciuitas Babylonis, estque huiusmodi congregatio simul orta cum Christi Ecclesia, et simul cum illa creuit, et est perseueratura vsque ad finem mundi, vt suo loco dicemus". 50b. 
orden a alcanzar el fin sobrenatural. De esta definición se deduce claramente que los bienaventurados no pertenecen a la Iglesia. Santo Tomás aplica esta definición a la Iglesia militante y triunfante. Pero la Iglesia, sobre la cual se va a tratar aquí, es la congregación de los fieles que caminan todavía por esta vida ${ }^{16}$. A ella se refiere en concreto el pasaje de la carta a los Efesios $(5,23)$ al hablar de Cristo como la cabeza de la Iglesia y como el salvador de su cuerpo. De la misma se dice más abajo (Ef 5,25-27) que Cristo la amó y se entregó por ella para santificarla, purificándola, mediante el lavado del agua, con la palabra, a fin de presentársela así gloriosa. Dirá además San Pablo en la misma carta (Ef 5,31-32) finalmente que dejará por esto el hombre a su padre y a su madre y se unirá a su mujer, y serán dos en una carne, lo cual es un misterio grande entendido de Cristo y de la Iglesia. Según Aragón, pretende el Apóstol señalar con tales palabras las cuatro causas de la Iglesia: eficiente, material, formal y final. Por el conocimiento de las mismas se llega ciertamente a poseer noticia perfecta de lo que es la Iglesia misma ${ }^{17}$.

En la Iglesia hay una doble causa eficiente: principal e instrumental. Cristo es la principal. Él la planta y la riega. Es algo en conformidad verdaderamente con el libro de Jeremías (2,21). Fue el mismo Cristo quien dijo, como consta en el evangelio de San Mateo $(16,18)$, que edificaría su Iglesia sobre esta roca: San Pedro. A esta causa principal es a la que hace referencia el Apóstol cuando llama a Cristo la cabeza de la Iglesia y el salvador de su cuerpo $(\mathrm{Ef} 5,23)^{18}$. La causa eficiente instrumental les corresponde a los sacramentos. Éstos vienen como derivación desde la pasión de Cristo. Son utilizados como los instrumentos de la piedad divina para la edificación del cuer-

16. "Vnde Ecclesia de qua in praesenti est sermo, diffinire poterimus, quod sit, Multitudo hominum fidelium, in fide et cultu vnius Dei conuenientium, ad finem supernaturalem comparandum. Quam diffinitionem ponit Glossa super capitulum Ecclesia, de consecratione d. 1. Ex quo infertur beatos non pertinere ad Ecclesiam, quem locum D. Tho. exponit tam de Ecclesia militante, quam de Ecclesia triumphante: tamen Ecclesia, de qua in praesenti loquimur, tantum significat, congregationem fidelium viatorum". 50b.

17. "De qua est intelligendus D. Paul. ad Ephe. 5. cum dicit, Christus est caput Ecclesiae, et saluator corporis eius: et paulo inferius Christus dilexit Ecclesiam, et tradidit semetipsum pro ea, vt illam sanctificaret, mundans eam lauacro aquae in verbo vitae, vt exhiberet eam sibi gloriosam Ecclesiam, etc. Et in fine eiusdem capitis, Propter hoc relinquet homo patrem et matrem, et adhaerebit vxori suae, et erunt duo in carne vna: sacramentum hoc magnum est, ego autem dico, in Christo et Ecclesia. Quibus verbis Apostolus tangere videtur quatuor causas Ecclesiae, scilicet, efficientem, materialem, formalem, et finalem, ex quarum cognitione ipsius Ecclesiae perfecta notitia colligi debet". 50b-51a.

18. "Causa efficiens duplex est, vna principalis, altera instrumentalis: principalis, est ipse Christus, qui Ecclesiam plantauit, atque fundauit: iuxta illud Hieremiae c. 2. Ego plantaui vineam electam. Et Matth. 16. Super hanc petram aedificabo Ecclesiam meam. Et hanc causam tangit Apostolus dicens, quod Christus est Caput Ecclesiae, et saluator corporis eius". 51a. 
po de la Iglesia. A esta causa instrumental se refiere San Pablo cuando habla del lavado de agua en la palabra de vida $(\text { Ef } 5,26)^{19}$. Los fieles son por otra parte la causa material de la Iglesia. Lo cual queda explicado por el Apóstol al mencionar el amor de Cristo a la Iglesia (Ef 5,25). Ésta es la reunión de los fieles ${ }^{20}$. Finalmente, es la unidad del cuerpo místico la causa formal. A ella alude San Pablo al señalar el gran sacramento referido a Cristo y a la Iglesia (Ef 5,32). Ahora bien, esta causa final es doble. Puede hacer referencia la misma a la vida presente: la santificación, o a la otra vida: la glorificación. La primera es la señalada por San Pablo al hablar de la santificación (Ef 5,25). A la segunda se refiere el Apóstol cuando habla de la presentación gloriosa (Ef $5,27)^{21}$.

Herejes y católicos coinciden en la afirmación de que esta Iglesia existente en estado de peregrinación por la tierra es una, santa, católica y apostólica. Así se sostuvo expresamente en el concilio primero de Constantinopla y en el de Calcedonia ${ }^{22}$. ¿Qué significan estas cuatro propiedades?

Es la Iglesia una de verdad gracias a la unidad de la fe, de la ley de Cristo y de los sacramentos. Se habla de una sola unidad de religión en la secta. Asimismo, se llama también una a la sociedad de los sarracenos y se la distingue de la de los idólatras pese a encontrarse y poder existir ambas civilmente en multitud de reinos. Lo mismo se aplicará también cuando se afirma de la Iglesia. Hay en ella unidad de religión pese a darse en la misma multitud y diversidad de reinos civiles. San Juan Crisóstomo y San Agustín fundamentan la unidad de la Iglesia precisamente en la unidad de la fe. San Jerónimo habla al respecto de la adoración al único Cristo y de la observancia de la única regla de $\mathrm{fe}^{23}$. Se dice a la Iglesia una además por la unidad del príncipe, o cabeza,

19. "Causa autem instrumentalis sunt sacramenta, quae Christi passione deriuata, tanquam instrumenta diuinae pietatis operantur ad aedificationem corporis Ecclesiae: et hanc tangit Apostolus cum dicit, Mundans eam lauacro aquae, in verbo vitae". 51a.

20. "Causa autem materialis sunt ipsi fideles: et haec explicatur dum dicitur, quod Christus dilexit Ecclesiam. Ecclesia enim, vt supra diximus, idem est quod collectio fidelium". 51a.

21. "Causa formalis est vnitas corporis mystici: et hanc tangit Apostolus cum dicit, Erunt duo in carne vna: sacramentum hoc magnum est, ego autem dico in Christo et Ecclesia. Et tandem causa finalis est duplex, vna in praesenti, quae est sanctificatio: altera quae expectatur in alia vita, et est glorificatio. Priorem tangit Apostolus dicens, vt illam sanctificaret: secundam autem dum dicit, vt exhiberet ipse sibi gloriosam Ecclesiam". 51a.

22. "Tertio est aduertendum, quod omnes tam Catholici, quam haeretici conueniunt in hoc, quod ita Ecclesia de qua loquimur est Vna, Sancta, Catholica et Apostolica: vt habetur expresse in concilio Constantinopolitano 1. cap. 7. et in Chalcedonensi actione 2. et in Niceno 2. actione 7.". 51a.

23. "Vna quidem, vnitate fidei, et legis Christi, et sacramentorum. Nam quemadmodum ab vnitate sectae, quoad religionen, dicitur vna respublica Sarracenorum, et altera Idolatrarum, quamuis quantum ad ciuilia, sint in ea multa regna, et plura esse possint: ita etiam, ab vnitate fidei, et sacramentorum, et legis Christi, dicitur vna Ecclesia quantum ad re- 
que la gobierna y rige: Jesucristo. Como indica San Pablo (Ef 4,15-16), fue el Padre quien colocó a Cristo como la cabeza sobre la Iglesia entera ${ }^{24}$.

Asimismo, se dice una a la Iglesia por la unidad de la esperanza que eleva a los bienes celestiales. Es lo expuesto en la carta a los Efesios $(4,4)$ sobre la esperanza de vuestra vocación. También es una por la unidad de la caridad, así como por la unidad del Espíritu. Es la perfección última y principal del cuerpo místico. Hay en la Iglesia diferentes gracias; pero el mismo es el Espíritu. Así lo dice San Pablo en la primera carta a los Corintios $(12,4)$. Como es la Iglesia una por tantos motivos, resulta que todos consienten en llamarla así. Se trata además de algo que está en consonancia con la Sagrada Escritura: Cant 6,8; Ef 4,4 y 1 Cor 10,1-2 25 .

A la Iglesia se le dice santa. Es realmente pura, limpia e inmaculada al regirse por reglas santas y puras. Cuenta además con los sacramentos, los cuales confieren la gracia y limpian a los hombres de sus bajezas para volverlos dignos ante Dios. Es llamada santa asimismo por el fin al que ordena y es ordenada: la santidad y la pureza de vida, de gracia y de gloria. Posee además los ministerios santos, los oficios y los grados, así como los dones divinos que le conducen a la santidad y que la gobiernan. Los herejes niegan lo anterior en relación a los sacramentos y a los órdenes eclesiásticos ${ }^{26}$.

ligionem, quamuis quantum ad ciuilia sint in ea multa regna, et plura esse possint. Si enim res diuina, in quam omnes fideles vocati sunt, est Christianae religionis fundamentum, vt dicit D. Chrysost. necessario ab vnitate huius fidei, Ecclesia, quae supra illam fundatur, erit dicenda vna. Propter quam fidei communitatem, dicit D. August. super Ioannem, Omnes vnum vos estis in Christo Iesu. Et D. Hierony. scribens ad Euandrum Episcopum, cuius verba referentur in c. legimus 93. dist. affirmat, nec altera Romanae vrbis Ecclesia, altera totius orbis existimanda est: et Galliae, Britanniae et Africae, et Persiae, et Oriens, et India, et omnes Barbarae nationes, vnum Christum adorant, vnam obseruant regulam veritatis". 51a-51b.

24. "Dicitur praeterea Ecclesia vna vnitate principis, seu capitis, quo gubernatur, et regitur: qui vnus est, scilicet, Christus Iesus, quem pater dedit caput super omnem Ecclesiam, quae est corpus eius, vt dicit Paul. ad Ephe. cap. 4.". 51b.

25. "Et etiam dicitur vna, vnitate spei, qua ad bona coelestia erigitur: iuxta illud ad Ephe. 4. Vocati estis in vnam spem vocationis vestrae. Et tandem est vna vnitate charitatis, qua connectitur, et vnitate spiritus, tanquam vltima et principalis perfectio corporis mystici, est in omnibus membris Ecclesiae, diuidens singulis prout vult. Diuisiones gratiarum sunt, idem autem spiritus, vt dicit Apostolus 1. ad Corinth. cap. 12. Cum ergo tot rationibus Ecclesia sit vna, conuenienter omnes consentiunt in hoc, quod Ecclesia vna appelletur. Vnde de ea dicitur Cant. 6. Vna est amica mea, columba mea. Et ad Ephe. 4. Vnum corpus, vnus spiritus, vnus Deus. Et 1. ad Corinth. 10. omnes nos in vnum corpus baptizati sumus". 51b.

26. "Dicitur deinde Ecclesia sancta, id est, pura, munda, et inmaculata, utpote quae regitur sanctis et puris regulis, habetque sacramenta, quibus gratia confertur, et mundantur homines a peccatorum sordibus, et decori fiunt apud Deum. Vel dicitur sancta, a fine ad quem ordinat et ordinatur, scilicet, ad sanctitatem, et puritatem vitae, gratiae, et gloriae. Habet etiam sancta ministeria, officia, gradus, et dona diuina, quibus ad sanctitatem ducitur, et gubernatur, quamvis hoc de sacramentis, et gradibus ecclesiasticis, negatur ab haereticis". 51b-52a. 
El nombre de católica se aplica a la Iglesia. De todas formas, debe advertirse que tal apelativo se refiere en concreto a tres realidades: la Iglesia, la fe cristiana y los fieles cristianos. Los cristianos confiesan la Iglesia católica. Además, en el símbolo de San Atanasio confiesan que ésta es la fe católica. Con San Jerónimo se llama también católico al cristiano. Éste dice en concreto que, si alguien le quiere culpar, comprobará que se trata de un inexperto o de un malévolo; hasta puede que sea hereje, además de no católico ${ }^{27}$. El adjetivo católico viene del griego. Traducido al latín es lo mismo que universal. A la fe se le dice católica primeramente por muchos motivos según Torquemada. El principal de ellos es por haber sido anunciada, plantada y sembrada la misma por todo el orbe y en todas las gentes. Así lo refiere en concreto el Salmo $(18,5)$ cuando habla de que su pregón sale por la tierra toda y sus palabras llegan a los confines del orbe. Isaías (60,3-5) refiere la vocación de los gentiles en el sentido de que ha de llegar un día en el que, por medio de Cristo, las gentes andarán a tu luz y los reyes, a la claridad de tu aurora; llegarán de lejos tus hijos y tus hijas serán traídas a ancas; cuando se vuelva a ti la multitud de mar, llegará a ti la fuerza de las gentes ${ }^{28}$.

A la Iglesia se le llama católica o universal también por las gentes de que consta. Se forma de personas redimidas de toda tribu, lengua, pueblo y nación según expresión del Apocalipsis (5,9). A este carácter universal de la Iglesia hacía referencia San Pedro cuando reconocía (Hech 10,34-35) que no hay en Dios acepción de personas, sino que en toda nación el que teme a Dios y practica la justicia le es acepto. También se le llama universal o católica en cuanto al lugar al hallarse extendida por el orbe entero. Asimismo, es universal en cuanto al tiempo al haber comenzado al inicio del mundo y por ser imposible que desfallezca en el futuro. Lo es asimismo universal en relación a las condiciones de los hombres. A nadie se le echa de la misma por una determinada condición. No se tiene en cuenta dentro de ella al amo, al siervo, al hombre, a la mujer, al

27. "Tertio dicitur Ecclesia Catholica. Pro quo est aduertendum, quod tribus rebus consueuimus hoc nomen Catholicorum tribuere, scilicet ecclesiae, fidei Christianae, et hominibus fidem Christi habentibus. Confitemur enim ecclesiam Catholicorum, cum beato Athanasio in suo symbolo, dicente, Haec est fides Catholica: et etiam vocamus Christianum Catholicum, cum D. Hieronymo, qui in c. haec est fides 24. q. 1. dicit. Quicumque me culpare voluerit, se imperitum, vel maleuolum, vel etiam non Catholicum, sed haereticum comprobabit". 52a.

28. "Catholicum autem, nomen Graecum est, idem Latine sonans, quod vniversale. Dicitur ergo primo, fides Christi Catholica, multis de causis, quas refert Turrecremata libr. 1. suae summae cap. 13. sed praecipua est, qua annunciata, plantata, et seminata fuit, per vniuersum orbem, et apud omnes gentes: iuxta illud Psal. 18. In omnem terram exiuit sonus eorum, et in fines orbis terrae verba eorum: Et Esai. cap. 60. (texto: 56.) gentium vocationem, quae per Christum futura erat, referens dicit: Ambulabunt gentes in lumine tuo, et reges in splendore ortus tui: filij tui de longe venient, et filiae tuae de latere surgent. Et rursus, Quando conuersa fuerit ad te multitudo maris, fortitudo gentium venerit tibi, etc." . 52a. 
griego o al judío. Como dice la carta a los Colosenses $(3,11)$, no hay cabida allí para distinciones entre hombre y mujer, gentil y judío, circuncisión e incircuncisión, bárbaro y escita, siervo y libre, porque Cristo lo es todo en todos ${ }^{29}$.

Es llamada la Iglesia apostólica por fundarse su fe sobre la doctrina de los Apóstoles. La carta a los Efesios $(2,20)$ habla de edificación sobre la doctrina de los Apóstoles y profetas. Asimismo, se le denomina de esta manera en cuanto se cree que todo rito de la religión cristiana y toda observancia de las instituciones sagradas ecclesiásticas se derivan por tradición apostólica. Así lo confiesa claramente San Agustín al decir contra los donatistas que se cree que ha sido entregado por los Apóstoles mismos lo que se guarda y se conmemora en toda la Iglesia pese a no haber constancia de ello en sus dichos o concilios. Es algo en lo que están de acuerdo católicos y herejes ${ }^{30}$.

De todas formas, los herejes dicen que la verdadera Iglesia de Cristo, la santa y la apostólica es la suya. Dicen también que no lo es la de los católicos. A causa de este convencimiento de los herejes se plantea la duda sobre cuáles son los signos y las notas con que se puede reconocer y distinguir la congregación verdadera de la falsa, la congregación de los fieles de la de Satanás. Conviene separar antes que nada lo seguro de lo inseguro. Es cierto a este respecto que la Iglesia verdadera ha estado unida y vinculada siempre con la auténtica doctrina y con el uso auténtico de los sacramentos. La misma no puede errar en materia de fe. Esto es algo en lo que consienten hasta los herejes ${ }^{31}$. Asimismo, es seguro que, aunque la doctrina constituya un signo cierto

29. "Dicitur autem Ecclesia Catholica, hoc est, vniuersalis, primo quantum ad gentes ex quibus constat, colligitur enim Ecclesia ex omni tribu, lingua, populo, et natione, iuxta illud Apocalyp. 5. Redemisti nos Deus in sanguine tuo, et ex omni tribu, lingua, populo, et natione, et fecisti nos Deo nostro regnum. Propter quod D. Petrus Acto. 10. dicebat, In veritate comperi, quia non est personarum acceptor Deus, sed in omni gente, qui timet eum, et operatur iustitiam, acceptus est illi. Dicitur etiam Ecclesia vniuersalis, seu Catholica, quoad locum, quia est toto orbe diffusa: et quoad tempus, quia a principio mundi incepit, et nunquam est defutura; et etiam quoad conditiones hominum, quia nullus ab Ecclesia eijicitur: non dominus, non seruus, non masculus, non foemina, non Graecus, non Iudaeus, iuxta illud Apostoli ad Colossens. 3. Non est masculus et foemina; Gentilis et Iudaeus, circumcisio et praeputium; Barbarus et Scytha: seruus et liber: sed omnia in omnibus Christus". 52a.

30. "Tandem Ecclesia dicitur Apostolica, tum quia quoad fidem fundatur, Supra doctrinam Apostolorum, vt constat ex illo ad Ephes. 2. superaedificati supra doctrinam Apostolorum, et Prophetarum: tum etiam quia omnis Christianae religionis ritus, et sacrarum institutionum Ecclesiasticarum obseruantia, a traditione Apostolica creditur in Ecclesia deriuata, vt in cap. Ecclesiaticarum 11. d. dicitur, illudque ita esse affirmat D. Aug. lib. 2. de baptismo contra Donatistas dicens, Illa quae per vniuersam custodiuntur Ecclesiam, ab ipsis Apostolis tradita, et commemorata creduntur, quamuis in eorum dictis vel concilijs non reperiantur. Itaque in his omnibus, tam Catholici, quam haeretici conueniunt". $52 \mathrm{~b}$.

31. "Sed quoniam haeretici dicunt, quod ipsorum congregatio est vera Christi Ecclesia, Sancta, atque Catholica, et non ea quae apud nos inuenitur, dubium est, quibus notis, atque signis possimus discernere, et distinguere veram Ecclesiam, a falsa, et congregationem fidelium, 
para conocer la Iglesia verdadera, es un signo oscuro y, consiguientemente, resulta menos útil a la hora de manifestarla. Precisamente, existe una gran discusión entre católicos y luteranos sobre cuál es la verdadera doctrina y el verdadero uso de los sacramentos. No se puede llegar a una solución desde semejante signo únicamente. Es imposible desde el mismo distinguir con suficiencia la Iglesia verdadera de la falsa. Por ello, es preciso usar nuevos signos ${ }^{32}$.

A la hora de reconocer cuál es la verdadera Iglesia frente a la falsa, debe tomarse como primer signo seguro, que además es claro y brillante, la concorde y unánime confesión de la fe cristiana entregada por los Apóstoles de palabra o por escrito y entendida además como la entendieron desde el inicio de la Iglesia naciente los santos padres, los Sumos Pontífices y concilios. Se señalará entonces como la verdadera Iglesia la que posea todo lo indicado con anterioridad. Se estará ante un signo claro y manifiesto en cuanto es evidente de quiénes son aquéllos cuya doctrina concuerda con el sentir de los santos padres y de los concilios. Se sabe de quiénes son los que siguen la autoridad de los santos y de los Sumos Pontífices en la inteligencia de la Escritura frente a los que persiguen inteligencias nuevas ${ }^{33}$.

Además, se prueba que se está ante un signo claro e infalible porque, al ser oscura la inteligencia de las Letras Sagradas y encontrarse la misma con muchas dificultades en cuanto da cada uno su particular intepretación al respecto, es algo coherente con la razón creer que la muy verdadera y muy cierta entre todas es la interpretación aprobada desde el inicio de la Iglesia naciente por tantos santos padres y concilios frente a la que han descubierto unos pocos hombres que son además de conducta escandalosa. Ciertamente,

a congregatione Sathanae. In qua re, vt certa ab incertis separemus, dico primo, certum esse, quod vera Ecclesia semper est coniuncta atque copulata cum vera Christi doctrina, et vero vsu sacramentorum, ita vt infra dicemus, vera Ecclesia, in ijs quae sunt fidei, errare non potest, ipsis etiam haereticis consentientibus". 52b.

32. "Dico secundo, etiam esse certum, quod quamuis vera doctrina sit certum signum ad cognoscendam veram Ecclesiam, est tamen signum obscurum, atque ex consequenti minus vtile ad illius manifestationem. Nam cum de hoc ipso, scilicet, quaenam sit vera doctrina, et verus usus sacramentorum, sit nobis magna concertatio cum haereticis, fieri non poterit, vt ex eo veram Ecclesiam a falsa sufficienter distinguere possimus: et sic alijs nouis signis vtendum erit". 52b.

33. "Dico ergo, primum signum, non solum certum, sed etiam manifestum, et illustre ad discernendam veram Ecclesiam a falsa sumendum esse ex concordi et vnanimi confessione fidei Christianae, quam nobis Apostoli verbo et scripto tradiderunt: intellectae eo modo, quo ab initio nascentis Ecclesiae sancti Patres, et summi Pontifices, atque concilia, intellexerunt: ita vt eam solam veram Ecclesiam dicamus, in qua haec omnia inueniuntur. Et quod hoc sit manifestum, et clarum signum patet: nam euidens est quinam sint illi, quorum doctrina concordat cum sensu sanctorum patrum, et conciliorum, et qui homines sequantur, in intelligentia scripturae, autoritatem sanctorum, et summorum pontificum: et qui sectentur nouas intelligentias". 52b-53a. 
son aquéllos y no éstos, quienes ofrecen la prueba legítima. Es lo que expone San Agustín contra los maniqueos. A ello hace referencia lo existente en los libros del Deuteronomio $(32,7)$ y de Job $(8,8)$ sobre la interrogación a los padres en orden al conocimiento de la verdad. El Salmo $(43,2)$ refiere cómo nos lo contaron nuestros padres. El libro de los Proverbios $(3,5)$ indica que no hay que apoyarse en la propia prudencia. Este pasaje es glosado en el sentido de no anteponer el propio sentido al de otros, sobre todo a la opinión de los doctores. El Eclesiástico $(8,11)$ recomienda no despreciar las sentencias de los ancianos ${ }^{34}$.

De todo lo anterior se desprende a las claras que la Iglesia verdadera de Cristo es la congregación de personas que, tras permanecer éstas fieles a Cristo en la fe y en el uso de los sacramentos, mantiene la doctrina extraída unánimemente desde las Letras Sagradas y Apostólicas, así como desde la tradición antigua gracias a los santos padres y a los concilios ${ }^{35}$.

Cuando se han establecido los signos para distinguir la Iglesia verdadera, se plantea la duda de si la misma es una o son muchas. De hecho, el rey de Inglaterra Enrique VIII mantuvo erróneamente que había tantas Iglesias como reinos, así como que cada rey se constituía en la cabeza suprema de la Iglesia de su reino. Terminaba proclamando incluso la existencia de tantas cabezas no subordinadas entre sí como reyes ${ }^{36}$. Que la Iglesia no sea una de verdad se pretende probar primeramente desde lo escrito por San Pablo en la carta a los Gálatas $(1,2)$. Allí se habla expresamente de las Iglesias de Galacia. Asimismo, se echa mano de la alusión de San Juan en el Apocalipsis $(1,11)$ sobre las siete Iglesias concretas existentes en Asia. Consecuencia de todo ello

34. "Quod vero, etiam sit hoc signum clarum, et infallibile probatur, nam cum sanctarum literarum intelligentia sit obscura, et multis difficultatibus implicata, ita vt singuli singulas asserant intelligentias, consentaneum est rationi, quod credamus ex omnibus eam esse verissimam, et certissimam, quam ab initio nascentis Ecclesiae tot sancti patres, atque concilia, approbarunt, et non eam quam pauci, et flagitiosi homines adinuenerunt. Siquidem illi, et non isti, legitimam faciunt probationem: vt docet D. August. libr. 2. contra Manichaeos. Et ad hoc facit illud Deutenonom. cap. 32. et Iob c. 8. Interroga patres tuos, et annuntiabunt tibi, scilicet, veritatem. Et Psalm. 42. Patres nostri annunciauerunt nobis: et Prouerb. 3. Ne innitaris prudentiae tuae, super quae verba dicit Glossa, illum inniti suae prudentiae qui suum sensum, aliorum et maxime doctorum sententiae, anteponit. Et Ecclesias. 8. Ne te praetereat narratio seniorum". 53a.

35. "Ex quibus omnibus infertur, veram Christi Ecclesiam, esse eam hominum congregationem, qui in Christum credentes, in fide et vsu sacramentorum, tenent eam doctrinam, quam ex sacris et Apostolicis literis, et ex antiqua traditione, Sancti patres atque concilia vnanimiter elicuerunt". 53a.

36. "Constituto iam Ecclesiam constare ex omnibus fidelibus tanquam partibus, dubium est, vtrum sit vna vel plures? In qua re fuit error Henrici regis Angliae asserentis tot esse Ecclesias quot sunt regna: constituebat enim vnumquemque regem summum caput Ecclesiae: et sic dicebat, tot esse capita inter sese non subordinata, quot erant reges". 66a. 
será deducir que las Iglesias son muchas ${ }^{37}$. También puede establecerse un argumento desde la razón para probar que hay muchas Iglesias. Se muestra cómo los catecúmenos pertenecen a la Iglesia en cuanto pueden salvarse, así como que no se hallan contenidos en ella por no haber recibido todavía el bautismo. La consecuencia de esta situación será admitir dos Iglesias por lo menos ${ }^{38}$. Además, no debe olvidarse que es preciso constituir multitud de cuerpos donde hay multitud de cabezas, las cuales no están subordinadas las unas a las otras. ¿Existen muchas cabezas realmente no subordinadas entre sí? Se responderá a la pregunta afirmativamente y se señalará como prueba ilustrativa el caso concreto de los obispos. Deberá haber entonces tantas Iglesias como obispos. San Cipriano refiere además que el obispo no puede ser juzgado por otro. Es verdad también que todos los obispos han sido constituidos por Cristo, lo que hace que deban ser depuestos por Él ${ }^{39}$.

Aragón mantiene como conclusión de fe que la Iglesia es una. La prueba de ello la pone en el Cantar de los Cantares $(6,8)$ cuando se habla de que es única mi paloma, mi perfecta. También el símbolo comenzado en Nicea dice: Creo una Iglesia católica y apostólica ${ }^{40}$. Se le dice una a la Iglesia por muchas razones. Se le llama así en primer lugar por la unidad de la cabeza: Cristo. La carta a los Efesios $(1,22)$ señala que Cristo fue puesto como cabeza de todas las cosas en la Iglesia. Se le llama una en segundo lugar por la unidad del vicario que hace las veces de Cristo en la tierra: el Sumo Pontífice. El evangelio de San Juan $(10,16)$ se hace eco de las palabras de Cristo anunciando cómo habrá finalmente un solo rebaño y un solo pastor, así como también se hace eco de que se le encargó a San Pedro que apacentara sus ovejas $(21,17)^{41}$.

37. "Et quidem quod Ecclesia non sit vna, probatur primo ex Paulo ad Galat. 1. vbi salutat Ecclesias, quae sunt Galatiae. Et Ioan. in Apocalyp. c. 1. facit mentionem septem Ecclesiarum, quae sunt in Asia, ergo sunt plures". 66a.

38. "Item, ratione sic argumentor, Cathecumeni pertinent ad Ecclesiam, siquidem saluari possunt, et tamen non continentur in Ecclesia Christi: quia non sunt baptizati, ergo ad minus sunt duae Ecclesiae". 66a.

39. "Tertio, vbi sunt plura capita non subordinata, necessario sunt plura corpora constituenda: sed tot sunt capita non subordinata, quot sunt Episcopi, ergo et tot sunt Ecclesiae. Consequentia cum maiori est nota, et minor probatur testimonio Cypriani, qui vt refert D. Aug. libr. de baptismo contra Donatist. cap. 2. dicit, quod nullus Episcopus potest ab alio iudicari: sed omnes a Christo, vel constitui, vel deponi possunt". 66a-66b.

40. "In hoc tamen sit prima conclusio, De fide tenendum est, quod Ecclesia est vna. Probatur ex illo cant. 6. Vna est columba mea, vna est perfecta mea, etc. Et ex symbolo Niceno vbi dicitur, Credo vnam Catholicam et Apostolicam Ecclesiam, etc.". 66b.

41. "Secunda conclusio, Ecclesia dicitur vna multis rationibus: nam primo dicitur vna vnitate capitis, quod est Christus: iuxta illud ad Ephes. 1. Ipsum dedit caput supra omnem Ecclesiam. Secundo dicitur vna vnitate vicarij, scilicet summi Pontificis, qui in terris gerit vicem Christi. Vnde dicitur Ioan. 10. Erit vnum ouile et vnus Pastor, et Ioan. vlt. dictum est soli Petro, Pasce oues meas". 66b. 
Asimismo, es una la Iglesia por la unidad de la fe en la que brilla y se funda. Decía San Agustín que todos somos uno. La carta a los Gálatas $(3,28)$ habla asimismo de esta unidad de todos en Jesucristo, lo cual es glosado en referencia a la unidad de la Iglesia. San Jerónimo afirma que no hay que separar la Iglesia de la urbe romana de la de todo el mundo en cuanto, en ellas, se adora al único Cristo y se respeta la regla única de la verdad ${ }^{42}$.

Otro motivo para llamar a la Iglesia una es la unidad del Espíritu, el cual protege y vivifica a todos los miembros de ella según lo escrito en la carta a los Efesios $(4,3)$ sobre la solicitud por conservar la unidad del Espíritu mediante el vínculo de la paz. Es ésta una manera de decir que los cristianos han de preocuparse por guardar la unidad eclesiástica realizada por el Espíritu Santo en orden a que, como dice la glosa, ser un solo cuerpo ${ }^{43}$. Es una también la Iglesia por usar los únicos y los mismos sacramentos conforme a lo escrito en la carta a los Efesios (4,5): un solo Señor, una sola fe y un solo bautismo ${ }^{44}$. Es asimismo una en razón de la unidad de la esperanza por la que se eleva a los bienes celestiales, así como por la unidad de la caridad, la cual une y vivifica. Sobre la primera habla San Pablo en la carta a los Efesios $(4,4)$ al recordar la esperanza de la vocación a la que han sido llamados los cristianos. Sobre la segunda, la carta a los Filipenses $(2,2)$ insta a tener la misma caridad y el mismo sentir ${ }^{45}$. Finalmente, es una la Iglesia por la unidad del fin al que todos tienden: la visión clara de Dios. La parábola de los trabajadores enviados a distintas horas a la viña se halla escrita en el evangelio de San Mateo (20,1-16). Allí se menciona un denario como el jornal que a todos se paga. Este denario es entendido por los doctores santos como el

42. "Tertio dicitur vna vnitate fidei, qua illustratur, et in qua fundatur: iuxta illud D. August. super Ioan. c. 17. Omnes vnum sumus, iuxta illud Apostoli ad Galat. 3. Omnes vnum vos estis in Christo Iesu, id est, in fide Iesu, vt Glossa interpretatur. Et D. Hieronymus scribens ad Euandrum Episcopum, vt habetur in c. legimus 93. d. dicit, Nec altera Romanae vrbis Ecclesia, altera totius orbis existimanda est, et Galliae, Britanniae, et Africae, et Persiae, et Oriens, in India, et omnes barbarae nationes, vnum Christum adorant, vnam obseruant regulam veritatis". 66b.

43. "Quarto dicitur vna vnitate spiritus foventis, et viuificantis omnia membra, iuxta illud ad Ephe. 4. solliciti seruate vnitatem spiritus in vinculo pacis, id est, solliciti seruare vnitatem Ecclesiasticam, quam facit Spiritus sanctus, vt vnum corpus sitis opere Spiritus sancti, vt dicit Glossa super illum locum". 66b.

44. "Quinto, Ecclesia dicitur vna, quia vtitur vnis et eisdem sacramentis; iuxta illud Paul. ad Ephe. 4. Vnus Dominus, vna fides, vnum baptisma". 66b.

45. "Sexto dicitur vna vnitate spei, qua ad bona caelestia erigitur, et vnitate charitatis qua connectitur et viuificatur. De spe dicit Apostolus ad Ephes. 4. Vocati estis in vnam spem vocationis vestrae. De charitate autem ad Philip. 2. Eandem charitatem habentes, vnanimes idipsum sentientes, etc.". 66b. 
mismo salario a todos los fieles por sus trabajos. Aragón invita a leer a este respecto la exposición de Torquemada ${ }^{46}$.

La Iglesia fue siempre una; pero fue ciertamente más una en un tiempo que en otro. La Iglesia actual es más una que la que existió antes de la venida de Cristo. Ahora es una por la unidad de un solo vicario. No tenía un solo vicario la que se dio antes de la venida de Cristo. El que presidía a los judíos no era el presidente de los gentiles ${ }^{47}$. Por otra parte, la Iglesia actual cuenta con los únicos y los mismos sacramentos, así como tiene también la misma ley. La que existió antes de la venida de Cristo no poseía los mismos sacramentos, ni la misma ley. Mientras los judíos se servían de la ley escrita y de los sacramentos mosaicos, los gentiles usaban la ley natural y los sacramentos en la misma establecidos. Todo ello lleva a concluir que la Iglesia actual es más una que la que existió con anterioridad a la venida de Cristo ${ }^{48}$.

A la existencia de muchas Iglesias se responde que las partes de ella se llaman a veces Iglesias particulares. De ellas se forma a todas luces la Iglesia una y universal. Particulares eran las Iglesias de Asia y de Galacia ${ }^{49}$. Sobre el argumento establecido a partir de la situación de los catecúmenos, se responderá que hay tres posibles maneras de pertenecer a la Iglesia: sólo en cuanto al número, sólo en cuanto al mérito, y en cuanto al número y al mérito al mismo tiempo. Como número solamente, pertenecen a la Iglesia los pecadores bautizados. En cuanto al mérito, le pertenecen todos los justos aunque no se hallen bautizados; es el caso de los catecúmenos. En cuanto al número y al merito al mismo tiempo, pertenecen a la Iglesia los justos bautizados. Hay constancia así de que los catecúmenos no pertenecen a una Iglesia distinta de

46. "Tandem est vna, vnitate finis, ad quem omnes tendunt, scilicet, ad claram Dei visionem. Vnde idem denarius, per quem doctores sancti beatitudinem intelligunt, omnibus fidelibus pro mercede laborum legitur assignatus, Matthaei 20. De hac conclusione videndus Turrecremata, libr. 1. suae summae c. 6. et 7.". 66b-67a.

47. "Tertia conclusio, Quamuis Ecclesia semper fuerit vna, tamen in vno tempore fuit magis vna, quam in alio. Probatur, nam Ecclesia, quae nunc est, est magis vna quam ea, quae fuit ante Christi aduentum, ergo. Antecedens probatur, Ecclesia, quae nunc est, est vna vnitate vicarij, et tamen illa, quae fuit ante Christi adventum, non habebat vnum vicarium, ille enim, qui praesidebat Iudaeis, non praesidebat Gentilibus". 67a.

48. "Item, Ecclesia quae nunc est, habet vna et eadem sacramenta, et eandem legem: et tamen ea, quae fuit ante Christi adventum, non habebat eadem sacramenta, nec eandem legem: Iudaei enim vtebantur lege scripta, et sacramentis Mosaycis: Gentiles vero vtebantur lege naturae, et sacramentis, quae in illa erant statuta, ergo Ecclesia, quae nunc est, est magis vna quam ea, quae fuit antea". 67a.

49. "Ad primum argumentum respondetur, quod partes Ecclesiae, interdum Ecclesiae appellantur partiales tantum, ex quibus vna, et vniuersalis Ecclesia conficitur, et tales erant Ecclesiae Assiae et Galatiae". 67a. 
la de Cristo ${ }^{50}$. Ciertamente, se acepta que los obispos sean cabezas no subordinadas en relación a sus Iglesias particulares; pero éstas se hallan subordinadas en relación a la Iglesia universal. Precisamente, se forma una sola Iglesia universal a partir de las Iglesias particulares bajo una sola cabeza: el Papa. Así se mostrará más adelante cuando se hable del Sumo Pontífice ${ }^{51}$.

¿Cuándo comenzó a existir la Iglesia de Cristo y hasta cuándo ha de durar la misma? Se dan al respecto varias opiniones de los doctores. Ciertos herejes dicen que la Iglesia se inició después del nacimiento de Cristo. Entonces resultará que la existente en los padres del antiguo testamento no sería la Iglesia. Prueban su opinión primeramente con las palabras del evangelio de San Mateo $(16,18)$ dichas al Príncipe de los Apóstoles de tú eres Pedro y sobre esta roca edificaré yo mi Iglesia. Si se sostiene que la Iglesia se encuentra fundamentada en San Pedro, se seguirá con claridad también que la misma no existió antes de la venida de Cristo. En segundo lugar, se fijan en que la verdadera Iglesia no puede existir sin verdadera fe. Dirán entonces los herejes que, antes de la venida de Cristo, no hubo fe verdadera. Aportan diferentes pruebas. San Pablo sostiene en la carta a los Gálatas (3,24-25) que la ley fue nuesto ayo para llevarnos a Cristo, para que fuéramos justificados por la fe; pero, una vez llegada la fe, ya no estamos bajo el ayo. Es una manera ésta de significar que no había fe antes de la venida de Cristo. La carta a los Hebreos $(11,13)$ habla además de los padres del antiguo testamento y afirma que en la fe murieron todos sin recibir las promesas ${ }^{52}$.

50. "Ad secundum de Cathecumenis respondetur, tripliciter posse contingere, quod aliquis ad Ecclesiam pertineat, scilicet, numero tantum, merito tantum, numero et merito simul. Tantum numero, pertinent ad Ecclesiam peccatores baptizati: merito vero, omnes iusti, quamuis baptizati non sint: vt Cathecumeni: numero, autem, et merito simul pertinent ad Ecclesiam, qui et iusti et baptizati sunt, et sic constat quod catehecumeni non pertinent ad aliam Ecclesiam praeter eam, quae est Christi". 67a.

51. "Ad tertium argumentum respondetur, quod quamuis Episcopi sint capita non subordinata in ordine ad suas Ecclesias partiales: subordinantur tamen in ordine ad Ecclesiam vniuersalem. Ex illis enim partialibus Ecclesijs efficitur vna vniuersalis, sub vno capite, quod est Papa: vt infra videbimus, cum de Summo Pontifice fuerit sermo". 67a.

52. "Aliud dubium est, a quo tempore inceperit Ecclesia, et quamdiu sit duratura? De qua re sunt variae doctorum sententiae. Quidam enim haeretici dicunt, Ecclesiam incepisse post Christi Natiuitatem, et quod ea, apud patres veteris testamenti, non fuerit. Quam suam sententiam probant primo, ex illo Matth. 16. Tu es Petrus, et super hanc petram aedificabo Ecclesiam meam: si ergo Ecclesia supra Petrum est aedificata, manifeste sequitur eam non fuisse ante Christi aduentum. Item secundo, Vera Ecclesia esse non potest sine vera fide: sed ante aduentum Christi non fuit vera fides, ergo. Consequentia cum maiori est nota, et minor probatur ex Paul. ad Galat. 3 dicente, Lex paedagogus noster fuit in Christo, vt ex fide iustificemur, at vbi venit fides, iam non sumus sub paedagogo. Quibus verbis aperte significat, fidem non fuisse ante aduentum Christi. Et ad Hebraeos 11. loquens de patribus veteris testamenti, dicit, Iuxta fidem defuncti sunt omnes, non acceptis repromissionibus". 67a-67b. 
San Agustín parece apoyar esta opinión de los herejes al escribir que la Iglesia empezó por Jerusalén y va por todas las naciones. También afirma el de Hipona en otro lugar que comenzó la Iglesia donde vino el Espíritu Santo del cielo. El Salmo $(9,15)$ habla de poder cantar tus alabanzas en las puertas de la hija de Sión, lo cual es glosado en el sentido que la hija de Sión es la Iglesia, así como que Sión generó todas las Iglesias del mundo por haber nacido allí donde comenzó la fe. El Salmo $(4,9)$ habla de dormir en paz apenas acostarse, lo cual es glosado ampliamente desde la pregunta de por qué no se añade que resurgirá. La explicación al respecto es que, como se tomó una costilla de la cual se formó Eva del costado de Adán, el cual era la figura de Cristo, durmió de la misma manera Cristo el sueño de la muerte para que, del lado del durmiente del que brotaron sangre y agua, que son los sacramentos de la redención, se formara también la esposa: la Iglesia. Lo mismo dice la glosa respecto al capítulo cuarto de la carta a los Efesios ${ }^{53}$.

Hubo otros autores que, desde el extremo contrario, afirmaron que la Iglesia surgió al mismo tiempo que los ángeles y que fue entonces cuando se inició. La prueba la colocan en que tuvieron los ángeles la gracia desde el mismo instante de su creación, así como en que poseyeron los mismos también la fe. No se olvide a este respecto que San Agustín dice que la Iglesia no es otra cosa que la congregación de los fieles. San Bernardo dijo que le plugo a Dios convocar la Iglesia de los hombres cuando tenía desde el principio como esposa a la inseparable multitud de los ángeles ${ }^{54}$. No falta otro grupo de autores, entre los que se halla Albert Pigge (el Campense). Dicen éstos que la Iglesia comenzó desde Adán y Eva con anterioridad al pecado. De hecho, tuvo Adán fe sobre la encarnación antes del pecado. Es algo que se deduce del libro del Génesis $(2,23)$. Es cuando exclamó Adán que esto es ya hueso de mis huesos y carne de

53. "Tandem haec sententia probatur ex D. Aug. qui super psal. 147. dicit, Cepit Ecclesia ab Hierusalem, et it per omnes nationes. Et in tractatu secundo super canonicam Ioa. dicit, Ibi inchoata est Ecclesia, vbi venit de caelo Spiritus sanctus. Et Glossa super illud Psal. 9. Vt annuntient omnes laudationes tuas in portis filiae Sion, dicit, Filia Sion est Ecclesia, Sion enim omnes Ecclesias mundi generauit, quia ibi nata est, vnde fides incepit. Et super Psal. 4. tractans illud, Numquid qui dormit, non adijciet vt resurgat? dicit, quod sicut de latere dormientis Adae, qui erat forma futuri Christi, assumpta est costa, de qua formata fuit Eua, ita dormiuit Christus somno mortis, vt de latere dormientis, de quo profluxerunt sanguis et aqua, quae sunt nostrae redemptionis sacramenta, formetur sponsa Ecclesia: et idem habetur in glossa ad Ephes. cap. 4.". 67b.

54. "Alii fuerunt in alio extremo, qui dixerunt, Ecclesiam simul cum angelis fuisse ortam, ab illisque initium habuisse. Quam suam sententiam probant ex eo quod angeli, statim a sua creatione, habuerunt gratiam; atque fidem, vt autor est D. Augu. lib. 12. de Ciuitate, sed Ecclesia nihil aliud est, quam congregatio fidelium, ergo: Item D. Bernard. Homil. 27. super Cantica, dicit, Cum haberet Deus a principio sponsam sibi inhaerentem multitudinem Angelorum, placuit ei, de hominibus Ecclesiam conuocare". 67b. 
mi carne, lo cual es interpretado por San Pablo (Ef 5,32) sobre Cristo al decir las palabras de que gran misterio es éste, pero entendido de Cristo y de la Iglesia. Asimismo, fue Adán miembro de Cristo por tener fe infomada por la caridad, lo cual le hizo ser miembro de algún cuerpo. Como la Iglesia es el cuerpo de Cristo, deberá reconocerse entonces que comenzó la misma con Adán ${ }^{55}$.

Conviene tener en cuenta antes de dar una respuesta definitiva que cabe hablar de dos maneras respecto a la Iglesia. En la primera de ellas, la Iglesia es considerada sólo como la congregación de hombres que hacen uso de la razón y tienen fe en Dios. En la segunda, se toma a Iglesia de manera más estricta. Se requiere además para formar parte de ella haber profesado la fe mediante un determinado signo visible. Así es como los doctores hablan comúnmente de la Iglesia. Así es también como se habla en este lugar. A este respecto cabe establecer además una distinción. La Iglesia puede ser considerada por la congregación de fieles que han profesado la fe mediante algún signo visible y, de manera estrictísima, se la debe considerar como la congregación que hace profesión de su fe mediante los signos y los sacramentos instituidos por Cristo ${ }^{56}$. Por estos motivos, cuando se habla de la Iglesia sin más como la congregación de las personas que poseen la fe, habría que reconocer que la misma se inició desde el momento en el que hubo ángeles ${ }^{57}$.

Si se habla de la Iglesia como la congregación de quienes han profesado su fe con un signo exterior, deberá tenerse como fe cierta que la misma comenzó antes de la venida de Cristo. Según la fe, debe sostenerse que hubo hombres antes de venir Cristo al mundo que profesaban su fe con signos exteriores. Es algo que se prueba, además de por tradición eclesiástica como lo hace San Agustín, por todo el antiguo testamento. En éste se menciona esa fe que tuvie-

55. "Alij autores, quorum vnus est Albertus Campensis, lib. 1. de Ecclesiastica Hierarchia c. 2 et 3. dicunt, quod Ecclesia incepit ab Adam et Eua ante peccatum. Idque probant primo, ex eo quod Adam ante peccatum habuit fidem de incarnatione, vt colligitur ex illo Genes. c. 2. Hoc nunc os ex ossibus meis, et caro de carne mea: quae verba Apostolus ad Ephes. 5. de Christo interpretatur dicens, Sacramentum hoc magnum est, ego autem dico in Christo et Ecclesia. Item Adam fuit membrum Christi, siquidem habuit fidem formatam charitate, ergo alicuius corporis fuit membrum: sed corpus Christi est Ecclesia: ergo Ecclesia incepit ab Adam". 67b-68a.

56. "Pro explicatione huius differentiae est aduertendum, quod de Ecclesia possumus loqui dupliciter, vno modo ita vt Ecclesia nihil aliud sit quam congregatio aliquorum ratione vtentium, qui fidem Dei habeant: alio modo magis stricte, pro congregatione fidelium, qui fidem suam signo aliquo visibili et Sacramentis protestantur, quo modo communiter Doctores loquuntur de Ecclesia: et nos etiam loquimur de praesenti, cum tantum agamus de Ecclesia visibili. Sed Ecclesia adhuc potest accipi dupliciter, vno modo pro quacumque congregatione fidelium fidem suam signo aliquo visibili protestantium, alio modo strictissime, pro ea congregatione, quae fidem suam protestatur, signis et sacramentis a Christo institutis". $67 \mathrm{~b}$.

57. "Hoc supposito sit prima conclusio, Loquendo de Ecclesia primo modo, certum est eam incepisse a conditione angelorum. Hanc conclusionem probant argumenta facta pro secunda opinione". 68a. 
ron los fieles que vivieron antes de Cristo y profesada por signos exteriores ${ }^{58}$. A ello no se oponen en modo alguno los argumentos ofrecidos al presentar la primera opinión. Así, cuando el Apóstol dice que, una vez venida la fe, ya no estamos bajo el ayo, está hablando sin más de la venida de la fe de Cristo. Es como si quisiera comunicar que la misma no existía con anterioridad. En el mismo capítulo se dice además que el justo vive por la fe (Gál 3,12). Respecto al texto de la carta a los Hebreos, se dirá que el autor prueba en largo discurso que todos cuantos alcanzaron la salvación la lograron por la fe. Aragón se ve precisado a decir que se habla aquí de la venida de la fe en cuanto a su manifestación. Se glosa entonces en concreto la expresión después de venir la fe en el sentido de después de ser revelada la misma, la cual estaba oculta para los antiguos. Nicolás de Lyra glosará ese mismo pasaje diciendo que la venida de la fe significa que ha llegado el tiempo de la revelación de la fe. De todas formas, reconocerá Aragón que esos pasajes pueden interpretarse de otra manera. Significa entonces la venida de la fe el cumplimiento de lo que iba a suceder en el futuro. Así se hablará más bien de que ha llegado la promesa. Se ha cumplido ciertamente lo prometido. En relación al texto de la carta a los Hebreos, recuerda Aragón cómo el autor afirma claramente que los antiguos murieron en la fe. En modo alguno significa el pasaje aludido que carecieran de la misma. Se afirma más bien en el mismo que la tuvieron como compañera y acompañante. Este texto fue además glosado en el sentido de que murieron adheridos a la fe ${ }^{59}$.

Cuando se habla de la Iglesia según la fe y según la profesión de la misma exteriormente, debe señalarse que comenzó desde el justo Abel. Es ésta una

58. "Secunda conclusio, Loquendo de Ecclesia secundo modo, quo modo praesens quaestio intelligenda est, certa fide tenendum est, eam incepisse ante Christi aduentum. Probatur, de fide tenendum est, ante Christi aduentum fuisse homines, qui fidem suam signis exterioribus protestarentur, ergo de fide est, ante illud tempus fuisse Ecclesiam secundo modo accepta: consequentia est nota, et antecedens probatur, non solum ex ecclesiastica traditione, vt autor est D. Aug. lib. 15. de Ciuit. et lib. de Catechizandis rudibus, a c. 18. vsque in finem: sed etiam ex toto veteri testamento, in quo sit mentio fidei signis exterioribus protestatae, quam fideles habebant ante Christi aduentum". 68a.

59. "Nec obstat testimonia adducta in argumento primae opinionis, quibus probabamus fidem non fuisse ante aduentum Christi, nam cum Apostolus dicit, Vbi fides venit, iam non sumus sub paedagogo, non loquitur de aduentu fidei Christi simpliciter, quasi voluerit significare, eam antea non fuisse: in eodem enim c. dicit, iustus ex fide viuit. Et ad Hebrae. 11. longo sermone probat, omnes quotquot salui facti sunt, per fidem saluos factos fuisse: sed loquimur de aduentu fidei secundum manifestationem: vnde Glossa sic habet, Vbi venit fides, id est, postquam reuelata est, quae prius occulta fuerat in antiquis. Et Nicolaus de Lyra, venit fides, id est tempus fidei reuelatae: vel potest exponi, venit fides, id est, impletum est illud, quod credebatur futurum: tunc enim promissio dicitur venisse, quin id, quod promittitur, adimpletur. Ad aliud ex epistola ad Hebr. c. 11 respondetur quod Apostolus dicit, Antiquos defunctos fuisse iuxta fidem, non quia eam non habuerunt, sed quia eam morientes habuerunt sociam, atque comitem. Vnde Glossa dicit, Iuxta fidem, id est, adhaerentes fidei mortui sunt". 68a-68b. 
conclusión común a todos los santos. Al hablar de la Iglesia, dice San Agustín que esta ciudad tuvo su origen en el justo Abel, mientras la ciudad mala tuvo su inicio en Caín. Es algo además que se prueba desde la razón. Cuando se habla de la Iglesia de la segunda manera, resulta imposible que se dé la misma sin signo alguno de profesión visible. Además de por lo ya expuesto, hay constancia de ello en muchos lugares de las obras del de Hipona. En el libro contra Fausto dice San Agustín que fue Abel el primero en hacer profesión de su fe. Es algo que consta además por el capítulo tercero del libro del Génesis ${ }^{60}$. La Iglesia ha perseverado siempre sin interrupción alguna desde el inicio primero, lo cual lleva a proclamar que el mismo debe colocarse en el justo Abel y no en Adán. Si la Iglesia hubiera comenzado a partir de Adán, habría quedado interrumpida durante el tiempo en el que permanecieron en pecado Adán y Eva. Es un hecho que la Iglesia no puede persistir sin caridad. Además, la carta a los Hebreos $(11,4)$ inicia en Abel la lista de quienes fueron justos y fieles en la Iglesia. Esto lleva a concluir que fue el primero en pertenecer a ella. Así lo prueba además con muchas otras razones Torquemada ${ }^{61}$. Quienes no se resisten a no colocar el inicio de la Iglesia en Adán insisten en que éste parece que hizo profesión de su fe mediante algún sacrificio y signo sensible. Apoyan su parecer en el Maestro (Pedro Lombardo). Éste cuenta que Adán enseñó a sus hijos a ofrecer las primicias y diezmos. También llaman la atención en que, cuando murió Abel, la Iglesia permaneció en Adán y Eva, lo cual es algo que confiesan los doctores todos. ¿Habrá comenzado entonces la Iglesia a partir de Adán? ${ }^{62}$.

60. "Tertia conclusio, Haec Ecclesia secundo modo sumpta initium sumpsit ab Abel iusto. Haec conclusio, quae communis est omnium sanctorum, probatur primo, ex D. Aug. qui super Psal. 142. loquens de Ecclesia dicit, Haec ciuitas initium sumpsit ab Abel iusto, sicut mala ciuitas a Cain. Idem etiam affirmat super Psal. 118. et lib. 15 de Ciuitate per multa capita. Item ratione idem probatur, Ecclesia secundo modo accepta esse non potest sine fide signo aliquo visibili protestata, vt constat non solum ex ijs, quae diximus, sed etiam ex D. Aug. in multis locis, et praecipue contra Faustum, sed primus, qui signis exterioribus fidem suam protestatus est, fuit Abel, vt patet ex Genes. c. 3. ergo ab illo ecclesia initium sumpsit". 68b.

61. "Et confirmatur, Ecclesia, vt postea dicemus, a tempore, quo primum incepit esse, semper perseuerauit, absque aliqua interruptione, ergo non ab Adam, sed ab Abel iusto initium sumpsit: patet consequentia, nam si ecclesia incepisset ab Adam, eo tempore interrupta esset, in quo Eua atque Adam peccauerunt, cum Ecclesia sine charitate esse non possit, ergo non ab Adam, sed ab Abel iusto incepit. Tandem probatur ex Paulo, qui ad Hebraeos 11. (texto: 12.) dum repetit omnes iustos atque fideles, qui fuerunt in Ecclesia, initium facit ex Abel, ergo ille fuit primus eorum, qui pertinebant ad Ecclesiam. Hanc eandem conclusionem probat pluribus alijs rationibus Turrecremata, libr. 1. suae summae c. $25 . "$. $68 \mathrm{~b}$.

62. "Et si quis obijciat contra illam Adam videtur suam fidem protestatus fuisse aliquo sacrificio et signo sensibili, dicit enim Magister in historijs, quod Adam docuit filios suos offerre primitias, atque decimas, ergo non ab Abel, sed ab Adam incepit Ecclesia. Item mortuo Abel Ecclesia mansit in Adam, atque Eua, vt omnes doctores fatentur, ergo etiam incepit ab Adam". 68b. 
A todo ello se responderá que, si es verdad que Adán enseñó a ofrecer a sus hijos primicias y diezmos, no es tan claro que el mismo Adán hiciera tales ofrendas. Esto lleva a la conclusión de que, pese a ser el primero de todos en poseer la fe, no se lee en lugar alguno que Adán ofreciese sacrificio alguno. Santo Tomás suministra la razón de por qué no se lee que Adán hiciera sacrificios. Señala la inconveniencia de que se significara el origen de la salvación al mismo tiempo en quien se anota también el origen del pecado. Es lo que parece haber querido señalar concretamente el autor de la carta a los $\mathrm{He}$ breos $(11,4)$ al hacer memoria de la fe de los padres del antiguo testamento y comenzar el recuerdo de la misma con las palabra referidas a Abel de que éste ofreció a Dios un sacrificio más excelente o de mayor precio que Caín, lo cual le valió ser declarado justo ${ }^{63}$. Es a todas luces más lo requerido para que se diga que la Iglesia comenzó en Adán que para que se afirme que, muerto Abel, continuó en él. Además, no es verosímil que no tuvieran Adán y Eva otros hijos pese a no ser mencionados por la Sagrada Escritura, los cuales habrían permanecido firmemente en la Iglesia ${ }^{64}$. Ciertamente, es posible que Adán caminara en la fe y en la gracia antes de incurrir en pecado; pero, como no hizo profesión de ella con algún signo exterior, lo cual es necesario para que haya Iglesia, no se dice que pertenezca a ella. Tampoco se afirmará entonces que comenzó a partir de Adán la Iglesia de la que se está tratando en este lugar ${ }^{65}$.

La Iglesia actual y la existente antes de la pasión de Cristo es una y es la misma. Todos los que fueron justos desde el principio del mundo hasta la actualidad, así como los que lo han de ser en el futuro, poseyeron la única y la misma fe. La Iglesia queda constituida por la fe. La carta segunda a los

63. "Ad primum respondetur negando antecedens, et ad id, quod adducitur ex Magistro in historijs, dico quod si verum est, quod Adam docuit filios offerre primitias, non est verum, quod ipse eas per se obtulerit: vnde quamuis sit primus eorum, qui habuerunt fidem, non tamen dicitur initium Ecclesiae. Ratio autem propter quam, non legitur Adam sacrificium obtulisse, assignatur a D. Tho. 2. 2. quaest. 85. artic. 1. qui dicit, id factum fuisse, ne in eo, in quo notatur origo peccati, simul etiam sanctificationis origo significaretur. Quod etiam notasse videtur Apostolus ad Hebr. 11. dum fidem Sanctorum Patrum veteris testamenti commemorans, ab Abel incipiens dicit, Fidei plurimam hostiam, id est, maioris precij, Abel quam Cain obtulit Deo, per quam testimonium conquutus est esse iustus, etc.". 68b-69a.

64. "Ad secundum respondetur concesso antecedenti negando consequentiam, plus enim requiritur ad hoc, vt Adam dicatur initium Ecclesiae, quam ad hoc, vt mortuo Abel in ipso Ecclesia perseueret: maxime quod non est verosimile, quod tunc Adam atque Eua non habuerint alios filios, qui firmiter ad Ecclesiam pertinebant, quamuis eorum mentionem non faciat scriptura". 69a.

65. "Ad alia autem argumenta adducta pro tertia sententia respondetur, quod quamuis Adam ante peccatum habuerit fidem et gratiam: quia tamen illam non est protestatus signo aliquo exteriori, quod necessarium est ad Ecclesiae rationem, non dicitur ad Ecclesiam pertinere, nec quod ab eo incoepit ea ecclesia, de qua nos in praesenti disserimus". 69a. 
Corintios $(3,12-18)$ muestra que todos pertenecen a la misma Iglesia cuando se habla de los justos de la ley nueva y de la antigua ${ }^{66}$. Se ha de creer también como de fe que la Iglesia actual iniciada a partir de Abel ha de durar hasta el fin del mundo. Esto se prueba con claros testimonios de la Sagrada Escritura. El Salmo $(47,9)$ afirma que Dios la hará subsistir siempre. Enseña precisamente San Agustín que este pasaje ha de entenderse referido a la Iglesia. Lo hace cuando se pregunta si esa ciudad que tuvo el mundo será arrasada alguna vez. Lo rechaza el de Hipona y da como razón que la fundó Dios para siempre. Entonces, si las cosas están así, termina diciendo que no hay temor a que se derrumbe su fundamento. En el libro de Isaías $(9,7)$ se dice en concreto que el Príncipe venidero dilatará su imperio y dará una paz ilimitada, sentándose sobre el trono de David y sobre su reino para afirmarlo y consolidarlo en el derecho y la justicia desde ahora para siempre. El evangelio de San Lucas (1,32-33) indica a Cristo en clara referencia a la Iglesia diciendo que reinará en la casa de Jacob por los siglos, y su reino no tendrá fin. El profeta Oseas $(2,19)$ se hace eco de la voluntad de Dios de esposarse para siempre con la Iglesia en fe eterna. El evangelio de San Mateo $(16,18)$ transcribe las palabras famosas de Cristo referidas a Pedro de que las puertas del infierno no prevalecerán contra la Iglesia. Ciertamente, prevalecerían las mismas si pereciere la Iglesia antes del fin del mundo ${ }^{67}$.

¿Ha desfallecido la Iglesia alguna vez desde su inicio? A este respecto debe decirse que la Iglesia nunca ha dejado de existir desde el momento mismo de su inicio, así como debe decirse también que nunca desfallecerá en el futuro. Además de probarse esta conclusión por la tradición de la Iglesia, hay constancia de ella por San Agustín. Afirmó explícitamente éste que

66. "Quarta conclusio, Haec Ecclesia, quae nunc est, et ea, quae fuit ante Christi passionem, est vna et eadem Ecclesia. Probatur, omnes iusti, quotquot fuerunt ab initio mundi vsque ad istud tempus, et quotquot postea sunt futuri, habuerunt vnam et eandem fidem, ergo pertinent ad vnam et eandem Ecclesiam, patet consequentia: nam Ecclesia per fidem constituitur: antecedens vero probatur ex Paul. 2. ad Corinth. c. 3. (texto: 4.) vbi loquens de iustis nouae et antiquae legis ostendit, omnes pertinent ad eandem Ecclesiam". 69a,

67. "Sexta conclusio: De fide tenendum est quod haec Ecclesia, quae ab Abel incoepit, vsque ad finem mundi sit duratura. Probatur apertis testimonijs sacrae scripturae, et primo ex illo Psal. 47. Deus fundauit eam in aeternum. Quem locum intelligendum esse de Ecclesia, docet $\mathrm{D}$. Aug. dicens, Forte ista ciuitas, quae mundum tenuit aliquando euertetur? Absit. Deus fundauit eam in aeternum. Si ergo Deus fundauit eam in aeternum, quid times ne cadat firmamentum? Et Esai. cap. 9. dicitur de regno Ecclesiae, quod multiplicabitur imperium eius et pacis non erit finis. Super solium Dauid et super regnum eius sedebit, vt confirmet et corroboret in iudicio, et iustitia, amodo et vsque in sempiternum. Et Lucae c. 1. dicitur de Christo, Regnabit in domo Iacob, id est in Ecclesia, in aeternum, et regni eius non erit finis. Et Oseae cap. 2. dicitur ad Ecclesiam ex persona Dei: Et sponsabo te mihi in fidem sempiternam, et Matth. 16. Portae inferi non praeualebunt aduersus eam: sed praeualerent si Ecclesia ante finem mundi esset interitura, ergo". 69a-69b. 
nunca dejó de haber Iglesia en la tierra desde el inicio del género humano. Se prueba además que la misma no ha de desfallecer en cuanto se seguiría de ello que dejaría de estar Cristo en medio de la Iglesia, lo cual es absurdo bajo todos los aspectos. Prometió Éste que había de estar con nosotros hasta la consumación del mundo. Por eso, habrá siempre en la Iglesia fe verdadera, caridad verdadera y uso verdadero de los sacramentos. Sin ellos no puede haber Iglesia ${ }^{68}$.

Cuestión diversa es la de averiguar en qué lugar y junto a qué personas se encuentra la Iglesia. Es lo mismo que si se pregunta si la verdadera Iglesia de Cristo está entre los alemanes o se halla más bien entre quienes obedecen al Pontífice de Roma. Los herejes luteranos sostienen a este respecto que la verdadera Iglesia de Cristo se encuentra sólo en ellos y que la congregación de la Iglesia romana es el grupico del Anticristo. Pero eso es precisamente lo que han dicho siempre todos y cada uno de los grupicos de los herejes. Terminan todos juzgando y profesando que ellos son principalísimamente los cristianos y que la suya es la Iglesia católica. Era lo que decía San Cipriano de Novaciano cuando éste reivindicaba que la Iglesia estaba junto a él y llamaba a los católicos herejes. Llamaba la atención de que no estaba Novaciano en la Iglesia. Afirmaba incluso que se había colocado como rebelde contra la Iglesia, así como que, al no estar en ella, se asemejaba a las monas que, pese a no ser personas, imitan a las personas. También lo advertía San Hilario al Emperador al decirle que, en su tiempo, la sinagoga del Anticristo se presentaba mendazmente como la Iglesia de Cristo. Sobre los donatistas dejó escrito San Agustín que solían decir que la Iglesia estaba sólo en el partido de Donato en cuanto la Iglesia estaba únicamente en África y no en toda la tierra. San Bernardo hablaba de cómo había en su tiempo quienes se decían apóstoles y afirmaban que la Iglesia se encontraba sólo en ellos. Aragón añade que esta temeridad fue seguida más tarde por los pobres de Lyón y que discípulos de ellos son los picardos ${ }^{69}$.

68. "Sed dubitatur aliquis hoc loco, vtrum Ecclesia a tempore suae inceptionis, aliquando defierit esse? (...) In hoc tantum sit septima conclusio, De fide tenendum est, quod Ecclesia ab eo tempore quo primum incoepit, nunquam desijt esse, nec deficiet aliquando. Haec conclusio, praeterquam quod probari potest ex Ecclesiae traditione, probatur ex D. August. qui super Psal. 118. dicit, Ecclesia nunquam defuit in terris ab initio generis humani. Quod autem nec etiam deficiet probatur, quia alias sequeretur, quod eo tempore Christus non esset apud nos, hoc autem est absurdum: nam ipse promissit quod futurus erat nobiscum, vsque ad consummationem saeculi, ergo. Ex dictis infertur, quod ab eo tempore, quo primum Ecclesia incoepit, semper fuit in mundo vera fides, vera charitas, et verus vsus sacramentorum: quia Ecclesia sine his constare non potest". $69 \mathrm{~b}$.

69. "Aliud dubium est, quonam loco, et apud quod homines, ista ecclesia sit quaerenda. Quod est quaerere, vtrum vera Christi ecclesia sit apud Germanos, vel potius apud eos, qui 
Es la verdadera Iglesia de Cristo, regida por el Espíritu Santo y fuera de la cual no hay salvación, la congregación de fieles que reconoce y sigue como su cabeza al Romano Pontífice: vicario de Cristo y sucesor de Pedro. Ésta no es otra ciertamente que la congregación que servía cuando escribía Aragón bajo el papa Gregorio XIII. En contra de lo afirmado por los herejes, es ésta una conclusión que ha de ser tenida como de fe. La verdadera Iglesia de Cristo es la que mantiene sobre la fe y los sacramentos lo contenido en las Sagradas Letras entendidas como lo hicieron los santos padres y los concilios. Esto se cumple precisamente en la Iglesia de Roma que está en el año 1584 sirviendo bajo Gregorio XIII; pero no sucede lo mismo en la Iglesia de los alemanes y de los herejes. Así se dirá como conclusión que la de Roma es la verdadera Iglesia de Cristo. Aragón dice que basta volver la vista atrás sobre lo dicho acerca de los signos para distinguir cuál es la Iglesia verdadera ${ }^{70}$.

La verdadera Iglesia de Cristo es además firme, invulnerable e inconmovible contra todas las furias y las tempestades. Es lo que se cumple en la Iglesia de Roma y no halla cumplimiento en la de los alemanes o herejes. Será entonces la romana la única verdadera. El evangelio de San Mateo (7,24-25) compara la Iglesia a la casa edificada sobre piedra firme, que no pudieron echar abajo la irrupción de los ríos ni el soplo de los vientos. Asimismo, se deduce lo anterior de lo expuesto en el mismo evangelio (Mt 16,18) sobre las puertas del infierno, que no prevalecerán contra ella. El Cantar de los Cantares $(9,7)$ dirá que es terrible como escuadrones ordenados. San Juan Crisóstomo enseña que la Iglesia romana es firme y estable, mientras no es así la de los herejes, en cuanto la de Roma es la única que tiene la misma fe

Romano Pontifici obediunt? Nam in hac re haeretici Lutherani dicunt, veram Christi ecclesiam esse apud ipsos, et quod congregatio ecclesiae Romanae est conuenticulum Antichristi, imo singuli quique coetus haereticorum, se potissimum Christianos, et suam esse catholicam ecclesiam existimant et profitentur. Vnde Cyprianus ad Iubanianum de Nouatiano dicebat, quod more simiarum, quae cum homines non sint, homines imitantur, cum ipse in ecclesia non esset, imo adhuc insuper contra ecclesiam rebellis extitisset, hoc sibi vendicabat, vt apud se ecclesiam esse diceret, ac nos haereticos faceret. Et D. Hilarius ad Constantium etiam affirmat, quod suo saeculo Antichristi Synagoga, Christi ecclesiam se esse mentiebatur. Et de Donatistis scribit D. Aug. epistola 56. et 166. quod ecclesiam in Africa tantum esse, et non in tota, sed solum in parte Donati contendebant. Et D. Bernar. sermone 66. in Cantica, dicit, suis temporibus fuisse etiam aliquos, qui se Apostolos vocabant, et ecclesiam apud ipsos esse dicebant, quorum temeritatem postea sunt imitati Pauperes de Lugduno, quorum suboles nunc sunt Picardi". 70a.

70. "Caeterum contra hos omnes haereticos est conclusio de fide tenenda, quod illa congregatio fidelium, quae Petri succesorem Christi vicarium Romanum Pontificem suum caput agnoscit, et sequitur, qualis est ea congregatio, quae nunc est sub Gregorio XIII. Summo Pontifice, est vera Christi ecclesia, de qua loquimur, quae regitur ab Spiritu sancto, et extra quam non est salus. Hanc conclusionem probo primo, nam vera Christi ecclesia est ea, quae 
mantenida desde el principio, mientras los herejes la han cambiado y extinguido cada vez más con el correr del tiempo. Lo afirmado ahora por la Iglesia es lo que surgió de ella. Se reconocerá entonces que la Iglesia que sigue al Pontífice de Roma es la firme y estable. Consecuentemente, es la verdadera Iglesia de Cristo ${ }^{71}$.

La Iglesia de Cristo verdadera es santa y perfecta a causa de la forma de vivir santa y honesta que se da en ella. Así se vive en la Iglesia de Roma y no en la de los luteranos. Es el símbolo el que ordena creer la Iglesia santa. Se requieren tres cosas para llevar una vida recta: religión para con Dios, sobriedad para con uno mismo y justicia para los demás. Así se deduce de las palabras del profeta Miqueas $(6,8)$ cuando expone que se ha declarado bien al hombre lo que es bueno y lo que de ti pide el Señor: hacer justicia, amar el bien, humillarte en la presencia de tu Dios. Lo primero pertenece a la sobriedad que debe tener el hombre para consigo mismo. Lo segundo forma parte de la justicia para con el prójimo. Lo tercero hace referencia a la religión para con Dios. En las tres indicaciones se halla a las claras la razón de vivir perfectamente. Con ello cuenta la Iglesia de Roma, mientras no existe tal cosa en la de los alemanes y herejes. Ante todo, hay religión para con Dios en la Iglesia de Roma, así como se halla el culto bien instituido en ella. Hay templos dispuestos, se utilizan en ella ministros y se sirve la misma de ceremonias convenientes. Entre los herejes y los alemanes no hay templos ni sacerdotes. Tampoco existe motivo alguno entre ellos para rezar y para alabar a Dios ${ }^{72}$.

de fide, et sacramentis, tenet illa, quae habentur in sacris literis, eo modo intellectis, quo sancti patres atque concilia intellexerunt: sed talis est ecclesia Romana, quae nunc est sub Gregorio XIII. et non ecclesia Germanorum, et haereticorum, ergo ecclesia Romana est vera Christi ecclesia, consequentia est nota, minor est euidens, maiorem vero probo ex ijs quae diximus, cum ageremus de signis, quibus ecclesia esset dignoscenda". 70a-70b.

71. "Secundo, vera Christi ecclesia est firma, inuiolabilis, et inconcussa manens contra omnes mundi turbines et procellas, sed talis est ecclesia Romana et non ecclesia Germanorum, aut haereticorum, ergo sola ecclesia Romana est vera Christi ecclesia: consequentia est nota, et maior patet ex illo Matth. 7. vbi ecclesia comparatur domui aedificata supra firmam petram, quam nec irruentes fluuij, nec ventorum flatus vertere poterunt: et ex illo quod dictum est Petro Matth. 16. Portae inferi non praeualebunt aduersus eam. Vnde in Canticis dicitur de illa, quod est terribilis tanquam castrorum acies ordinata. De quo videndus D. Chrysost. Homilia de expulsione sua, quae habetur in 5. tomo. Minor vero probatur, scilicet, quod ecclesia Romana sit firma et stabilis, et non ecclesia haereticorum: nam sola Romana ecclesia tenet eandem fidem, quam tenuit ab initio: et ecclesiae haereticorum saepesaepius sunt mutatae atque extinctae; id enim quod modo asseuerat, et fuit explosum ab ecclesia, ergo sola congregatio, quae sequitur Romanum Pontificem, est firma et stabilis, atque ex consequenti vera Christi ecclesia". $70 \mathrm{~b}$.

72. "Tertio probatur conclusio, vera Christi ecclesia est sancta, atque perfecta, propter sanctam et honestam viuendi rationem, quae in ea inuenitur: sed talis est ecclesia Romana, et 
Además, hay en la Iglesia de Roma mucho que da lugar a la sobriedad. Existen multitud de ayunos y se elige muy cuidadosamente los alimentos, lo cual no se da entre los alemanes. También se presta en la de Roma gran atención a la justicia para con el prójimo al enseñarse en ella que las obras buenas son meritorias para la vida eterna, mientras las malas llevan a merecer el suplicio eterno. Esto es despreciado como vaciedad por los alemanes al sostener que no es posible merecer o desmerecer ante Dios con obras justas o injustas. Salta entonces a la vista que la Iglesia de Roma es más santa que la de los alemanes. Consecuentemente, es ella la Iglesia verdadera ${ }^{73}$.

Es de tal forma católica y universal la verdadera Iglesia que se halla extendida por todo el orbe. Pertenece a todos los lugares, a todos los tiempos y a todas las naciones. De ello hay constancia por multitud de lugares de la Sagrada Escritura. De su difusión por todo el orbe hay constancia por el Salmo $(18,5)$ cuando se dice que su pregón sale por toda la tierra y sus palabras llegan a los confines del orbe. Asimismo, consta por el evangelio de San Marcos $(16,15)$; encomendó Cristo ir al mundo entero y predicar el Evangelio a toda criatura. Su extensión a todos los tiempos se comprueba por lo ya dicho sobre el inicio y la duración de la Iglesia. Que la misma abarque a toda clase de hombres consta desde lo expuesto por San Pablo en la carta a los Romanos $(10,12)$ sobre la inexistencia de distinción entre judío y gentil. También se comprueba por la carta a los Colosenses $(3,11)$ cuando se expone la inexistencia de distinción entre judío y griego, circuncisión e incircuncisión. Se hace referencia con ello a la nueva criatura. Esto se cumple en la Iglesia de Roma. De ello hay constancia por las historias. No se cumple en cambio en la de los alemanes o

non ecclesia Lutheranorum, ergo. Consequentia est nota, maior patet ex symbolo dicente, Credo sanctam ecclesiam, etc. Minor vero probatur: nam tria requiruntur ad rectam viuendi rationem, scilicet, religio in Deum, temperantia erga seipsum, et iustitia erga proximos, iuxta illud Micheae c. 6. Indicabo tibi, o homo, quid sit bonum, et quid dominus requirat a te, vtique facere iudicium, et diligere misericordiam, et solicitum ambulare cum Deo tuo. Primum pertinet ad temperantiam, quam debet homo habere erga seipsum. Secundum, ad iustitiam erga proximos, Tertium autem, ad religionem erga Deum, quibus perfecta viuendi ratio continetur: sed haec omnia inueniuntur in Ecclesia Romana, et non in Ecclesia Germanorum, aut haereticorum, ergo. Minor probatur, nam in primis religio erga Deum, et cultus diuinus est in Ecclesia Romana bene institutus, positis templis, et adhibitis ministris, atque caeremonijs ad id conuenientibus: cum apud haereticos et Germanos, nec templa sint, nec sacerdotes, nec vlla ratio Deum precandi, atque laudandi". 70b-71a.

73. "Item, in nostra ecclesia habetur magna ratio temperantiae, quod constat ex eo, quod apud nos sunt tot ieiunia, et tantus delectus ciborum, quarum rerum apud Germanos nulla est. Tandem, est etiam in nostra ecclesia maximus cultus iustitiae erga proximos, cum doceat bona opera esse meritoria vitae aeternae, mala autem supplicio aeterno, quae omnia Germani nihili faciunt dicentes, nec iustis, nec iniustis operibus posse nos aliquid mereri, aut demereri apud Deum, ergo Ecclesia Romana sanctior est quam ecclesia Germanorum: atque ex consequenti est vera Christi ecclesia". 71a. 
luteranos, la cual ha surgido hace sólo cuarenta años. Además, se halla incluida en una sola nación y en un rincón de la tierra. Consecuentememte, sólo es la Iglesia de Roma la Iglesia verdadera de Cristo ${ }^{74}$.

La Iglesia verdadera de Cristo es apostólica. Contiene y sigue la doctrina entregada por los Apóstoles. Es algo que le corresponde a la Iglesia de Roma y no a la de los alemanes o herejes. En el símbolo se confiesa la fe de la Iglesia una, santa, católica y apostólica. Ahora bien, la doctrina de los Doce no consta sólo por escrito. También hay constancia de ella por tradición. Así se desprende de las palabras de San Pablo en la carta primera a los Corintios cuando hace referencia a la eucaristía $(11,34)$ al decir que dispondrá todo a su llegada. San Agustín deduce de este pasaje que todo el rito del sacramento de la eucaristía fue entregado por el Apostol de palabra sin ser escrito. La primera carta a los Corintios $(11,2)$ recoge la alabanza de San Pablo a los hermanos por mantener lo mandado como les fue entregado. La carta segunda a los Tesalonicences $(2,15)$ se hace eco de la recomendación del Apóstol de mantenerse firmes y de guardar las enseñanzas que recibisteis, ya de palabra, ya por carta nuestra. San Juan reconoce en su segunda carta (1,13-14) que tendría que escribir muchas más cosas y que no quiere hacerlo con tinta y cálamo al esperar veros pronto y hablar cara a cara. Es algo esto que halla su confirmación en los escritos de San Ireneo, San Hilario, San Atanasio y Teodoreto. La Iglesia de Roma guarda las tradiciones de los Apóstoles. No lo hace así la de los alemanes y herejes. Sólo es entonces la de Roma la verdadera Iglesia de Cristo ${ }^{75}$.

Es la verdadera Iglesia de Cristo aquélla en la que se halla la legítima sucesión de los obispos y en la que se conecta ininterrumpidamente desde ellos mismos hasta los Apóstoles. Así se suceden siempre unos a otros tanto en la cátedra como en la confesión de la fe. Al respecto dirá San Ireneo que el conocimiento de la verdadera Iglesia se obtiene desde la doctrina de los

74. "Quinto probatur conclusio, Vera Christi ecclesia ita est Catholica et vniuersalis, vt sit diffusa per totum orbem, et pertineat ad vniuersa loca, et vniuersa tempora, et vniuersas nationes: vt constat ex pluribus locis sacrae scripturae. Nam primo, quod sit diffusa per totum orbem, patet ex illo Psal. 18. In omnem terram exiuit sonus eorum, et in in fines orbis terrae verba eorum, et ex illo Marci vltimo, quod dictum fuit Apostolis, Ite in mundum vniuersum et praedicate Euangelium omni creaturae, etc. Quod autem se extendat ad omnia tempora, patet ex ijs, quae diximus, cum de initio et duratione Ecclesiae ageremus. Et tandem quod se extendat ad omnia genera hominum, et ad omnes status, constat ex illo Paul. ad Roma. 10. Non est distinctio Iudaei et Graeci. Et ad Colos. 3. Apud Deum nec cincumcisio aliquid valet, nec praeputium, sed noua creatura: sed talis est ecclesia Romana, vt constat ex historijs, et non ecclesia Germanorum, aut Lutheranorum, quae ab hinc quinquaginta annis orta est, et inclusa in vna natione et angulo terrarum, ergo sola ecclesia Romana est vera Christi ecclesia". 71a-71b.

75. "Sexto, vera Christi ecclesia est Apostolica, hoc est, quae continet, et sequitur doctrinam traditam ab Apostolis: sed talis est ecclesia Romana et non ecclesia Germanorum, aut 
Apóstoles. El de Lyón añade además que se ha de obedecer solamente a los obispos que guardan la sucesión desde los Doce; son ellos quienes recibieron por sucesión del episcopado el carisma cierto de la verdad. Lo mismo dicen también San Agustín y Tertuliano. De todo ello se deducirá aquí que se encuentra únicamente en la Iglesia de Roma tal sucesión episcopal, tanto en la confesión de la fe como en la dignidad y en la cátedra. No se halla ésta en la Iglesia de los alemanes o de los herejes. Así consta desde las historias todas. Cae además fuera de toda duda que es únicamente la Iglesia de Roma la verdadera Iglesia de Cristo ${ }^{76}$. Además, es imposible olvidar que hay un orden en la verdadera Iglesia de Cristo. En ella, unos son prelados, otros son súbditos y otros ejercen diferentes funciones. Este orden se halla sólo en la Iglesia de Roma. No se observa en la de los alemanes o herejes. Éstos dicen que son sacerdotes y jueces eclesiásticos hasta las mujeres. Consecuentemente, es la Iglesia de Roma la única verdadera Iglesia de Cristo. Aragón invita a comprobar lo expuesto sobre esta conclusión por Estanislao Hosius ${ }^{77}$.

haereticorum, ergo. Consequentia est nota, maior patet ex symbolo, vbi dicitur, Credo vnam sanctam Catholicam et Apostolicam ecclesiam: minor autem probatur, nam doctrina Apostolica, non solum scripto, sed etiam traditione constat, vt patet ex Paulo 1. ad Corinth. vbi de Eucharistia sacramento dicit, Caetera cum venero disponam. Ex quo loco colligit D. August. epistola 118. ritum conficiendi sacramentum Eucharistiae fuisse traditum ab Apostolo, non scripto, sed verbis. Et 1. Cor. 11. (texto: 2. ad Timoth. cap. 2.) dicit Paul. Laudo vos fratres, quod sicut tradidi vobis praecepta, tenetis. Et 2. (2. falta en el texto) ad Thesalonicenses cap. 2. State, et tenete traditiones, quas didicistis, siue per sermonem, siue per epistolam. Et Ioannes secunda sua canonica dicit, Plura habens vobis scribere, nolui per chartam, et atramentum: spero enim me futurum apud vos, et ore ad os loqui. Idem etiam confirmat Ireneaus, lib. 3. c. 4. et D. Hilarius in libr. ad Constantinum Augustum, et Athanasius in lib. de decretis synodi Nicaenae, et Theodoretus aduersus gentes, lib. 1. cap. 8. sed ecclesia Romana seruat traditiones Apostolorum, et non Ecclesia Germanorum, aut haereticorum, vt constat, ergo sola Romana est vera Christi ecclesia". 71b.

76. "Septimo probatur conclusio, vera Christi ecclesia est ea, in qua inuenitur legitima successio Episcoporum, ab ipsis vsque Apostolis repetita, ita vt semper alij alijs succedant, tam in chatedra, quam in fidei confessione, vt constat ex Irenaeo, lib. 4. c. 63. vbi dicit, quod cognitio verae ecclesiae est ex Apostolorum doctrina, et antiquo ecclesiae statu, secundum successionem Episcoporum: et lib. 4. etiam dicit, quod illis tantis Episcopis est obediendum, qui successionem habent ab Apostolis: hi enim sunt, qui successione Episcopatus certum charisma veritatis acceperunt. Idem etiam docet D. August. contra Epistolam Manichaei c. 4. Et Tertullianus in lib. de praescriptionibus aduersus Haereticos: sed haec perpetua successio Episcoporum, tam in fidei confessione, quam in dignitate et cathedra, tantum inuenitur in Ecclesia Romana, et non in Ecclesia Germanorum, aut Haereticorum, vt constat manifeste ex omnibus historijs, ergo sola Romana est vera Christi ecclesia". 71b-72a.

77. "Vltimo sic argumentor, in vera Christi Ecclesia est ordo, ita vt alij sint praelati, alij subditi, alij alia munera exerceant: sed iste ordo tantum inuenitur in ecclesia Romana, et non in ecclesia Germanorum, aut haereticorum, qui dicunt omnes, etiam foeminas, esse sacerdotes atque iudices Ecclesiasticos, ergo sola Romana est vera Christi Ecclesia. De hac conclusione videndus est Hosius, Tomo 2. libr. 5.". 72a. 


\section{SEGUNDA PARTE}

Ecclesia es una palabra que viene del griego. En latín da reunión. Se llama Iglesia a la congregación de hombres que ha sido convocada previamente ${ }^{78}$. A la Iglesia de Cristo se le puede definir como la congregación de los fieles que, además de convenir en una misma fe y en un mismo culto del Dios único, ha sido reunida en orden a alcanzar un determinado fin sobrenatural $^{79}$. La naturaleza de la Iglesia aparece expuesta perfectamente en el capítulo quinto de la carta a los Efesios. Se forma la misma por cuatro causas: eficiente, material, formal y final ${ }^{80}$. La Iglesia se origina gracias a Cristo. Él fue quien la plantó y quien la regó. Él es la cabeza y el salvador de su cuerpo: la Iglesia ${ }^{81}$. Si Cristo es la causa eficiente principal, los sacramentos son en ella la causa eficiente instrumental. Surge la Iglesia cuando los mismos son utilizados por Cristo como instrumentos ${ }^{82}$. La Iglesia está formada por creyentes. Es la congregación de fieles, los cuales son su causa material ${ }^{83}$. Existe la Iglesia en orden a formar un solo cuerpo místico. Lo han de constituir Cristo y los fieles. La formación cada vez más perfecta del cuerpo místico se lleva a cabo gracias a la santificación continua de sus miembros en esta vida; pero su meta última es la glorificación final en el cielo por toda la eternidad ${ }^{84}$.

Según el credo iniciado en el concilio de Nicea, adornan a la Iglesia cuatro notas. Es una, santa, católica y apostólica. Sin discrepancia alguna son admitidas las cuatro tanto por los católicos como por los herejes ${ }^{85}$. ¿Qué significan en concreto las cuatro propiedades? La unidad indica ante todo que la Iglesia cuenta con la misma fe, la misma ley y los mismos sacramentos. La unidad de la Iglesia en nada impide a que la misma pueda establecerse en reinos diversos. No pierde por ello su unidad. Se otorga el apelativo de única también a la sociedad formada por los sarracenos y a la que reúne a los idólatras pese a abarcar una y otra reinos diversos ${ }^{86}$. La Iglesia de Cristo es una asimismo por estar sometida a un solo príncipe: Cristo. Él es la cabeza del entero cuerpo: la Iglesia ${ }^{87}$. Es una la Iglesia también por tener una única

\footnotetext{
78. Cf. nota 13.

79. Cf. nota 16.

80. Cf. nota 17.

81. Cf. nota 18.

82. Cf. nota 19.

83. Cf. nota 20.

84. Cf. nota 21.

85. Cf. nota 22.

86. Cf. nota 23.

87. Cf. nota 24.
} 
esperanza. A ella se encamina. Asimismo, es una por la unidad que le confiere la existencia en ella de la caridad y del Espíritu Santo. Cuenta ciertamente con distintas gracias; pero se da un único Espíritu en ella ${ }^{88}$. La Iglesia es además santa, lo cual quiere decir que es pura, limpia e inmaculada. Está regida además por reglas santas y puras. Cuenta con los sacramentos, los cuales facilitan que la Iglesia reciba la gracia y queden los hombres limpios de sus suciedades de forma que puedan presentarse dignos ante Dios. Es santa asimismo la Iglesia por el fin al que ordena y se ordena. Éste no es otro que la obtención de la santidad y de la pureza ${ }^{89}$.

Junto a los apelativos de una y de santa, se reconoce que la Iglesia de Cristo es católica y apostólica. El término católico viene del griego y equivale en latín a universal ${ }^{90}$. Se aplica a tres realidades: a la Iglesia, a la fe de Cristo y a los fieles ${ }^{91}$. A la Iglesia se le dice católica en primer lugar por las personas llamadas a ella. Todos son los convocados. No hay distinción de tribu, lengua, pueblo o nación. Dios no hace acepción de personas; le es acepto todo el que le teme y practica la justicia. Es también católica la Iglesia por hallarse extendida en el orbe entero. Asimismo, lo es en cuanto al tiempo. Existió desde el principio del mundo y durará hasta su final. No debe olvidarse a este respecto que no depende la misma de las condiciones de los hombres ${ }^{92}$. A la Iglesia se le reconoce la propiedad de la apostolicidad. Su fe está fundada en la doctrina de los Apóstoles. Así, se acepta sin discusión que todo rito de la religión cristiana y toda observancia de las instituciones eclesiásticas se derivan desde la tradición apostólica ${ }^{93}$.

Convienen ciertamente católicos y herejes en que la Iglesia de Cristo está adornada por las cuatro propiedades citadas. Es a todas luces una, santa, católica y apostólica ${ }^{94}$. ¿Puede decirse entonces que existe armonía perfecta sobre la Iglesia entre los unos y los otros? El agustino ha anotado de todas formas al comentar la santidad de la Iglesia cómo los herejes niegan la existencia de ministerios, oficios, grados y dones divinos, mediante los cuales la Iglesia es guiada y gobernada a la santidad ${ }^{95}$. Esta alusión general a los herejes apunta en concreto a los luteranos. Pese a reconocer los católicos y los luteranos unánimemente las cuatro notas que adornan a la verdadera Iglesia

88. Cf. nota 25 .

89. Cf. nota 26.

90. Cf. nota 27.

91. Cf. nota 28.

92. Cf. nota 29.

93. Cf. nota 30 .

94. Cf. notas 22 y 31 .

95. Cf. nota 26 . 
de Cristo, no es ocioso seguir preguntando en cuál de los dos grupos está de hecho la Iglesia única y verdadera de Cristo. ¿Se halla en la de los católicos o en la de los luteranos?

\section{Una}

Tiene el Cuerpo Místico una sola cabeza: Cristo; pero, ¿es admisible la existencia en la Iglesia única de Cristo multitud de cabezas? A esta pregunta respondía afirmativamente el rey de Inglaterra Enrique VIII al sostener que había tantas Iglesias de Cristo como diversidad de reinos. Indicaba incluso que había en el Cuerpo Místico tantas cabezas no subordinadas entre sí como reyes ${ }^{96}$. ¿Existe entonces en la tierra más de una sola Iglesia? A favor de ello hablarían determinados textos del nuevo testamento. San Pablo dirige el saludo a las diversas Iglesias de Galacia (Gál 1,2) y el Apocalipsis menciona las siete Iglesias de Asia (Apoc 1,11) ${ }^{97}$. Un argumento a favor de la existencia de más de una Iglesia en la tierra lo suministrarían también los catecúmenos. $\mathrm{Al}$ no haber sido bautizados, no se hallarán los mismos contenidos dentro de la Iglesia de Cristo; pero, como se salvan, será preciso reconocer que están dentro de ella. La lógica en estas circunstancias llevaría a reconocer la existencia de dos Iglesias distintas al menos ${ }^{98}$. Además, si se han de constituir tantos cuerpos distintos como cabezas no subordinadas existen las unas de las otras, debería aceptarse que hay muchas Iglesiạs. Habrá tantas como obispos independientes. San Cipriano y San Agustín indican que ningún obispo puede ser juzgado por otro, siendo Dios quien constituye a los obispos y quien los puede deponer ${ }^{99}$.

Pero estos argumentos, ¿no son fácilmente rebatibles? En modo alguno hay diversas Iglesias. Lo que ocurre simplemente es que a las partes de que consta la única Iglesia se les da el nombre de Iglesias particulares. De esta condición eran las Iglesias de Galacia y de Asia mencionadas por la carta a los Gálatas y por el libro del Apocalipsis ${ }^{100}$. El argumento esgrimido desde los catecúmenos se resuelve cuando se reconoce la existencia de tres modos diversos de formar parte de la única Iglesia. Los pecadores pertenecen a la misma únicamente en cuanto al número. Son contados como de la Iglesia. Los catecúmenos pertenecen a la misma sólo en cuanto al mérito. Ciertamente,

96. Cf. nota 36 .

97. Cf. nota 37.

98. Cf. nota 38 .

99. Cf. nota 39 .

100. Cf. nota 49. 
son capaces de merecer en ella. Los justos en gracia de Dios son quienes están unidos a ella en cuanto al número y en cuanto al mérito: son contados como miembros de ella y son capaces de merecer. Los catecúmenos no bautizados están consecuentemente dentro de la única Iglesia de Cristo ${ }^{101}$. Los obispos son a todas luces independientes como cabezas de las Iglesias particulares; pero eso no impide que guarden también una subordinación respecto a la Iglesia universal. La única Iglesia católica es la formada gracias a las Iglesias particulares bajo el sometimiento a una sola cabeza: el Papa ${ }^{102}$.

Ha de tenerse como de fe que la Iglesia de Cristo es una sola. Así se deduce de la Sagrada Escritura (Cant 6,8) y de la letra del símbolo comenzado en Nicea ${ }^{103}$. Diversos son los motivos que llevan a decir que la Iglesia es una: unidad de la cabeza: Cristo $(1,22)$; unidad del vicario de Cristo: el Sumo Pontífice (Jn 10,16 y 21,17) ${ }^{104}$; unidad de la fe: las palabras de ser uno en Cristo significan ser uno en la fe de Jesús (Gál 3,28) ${ }^{105}$; unidad del Espíritu: Éste favorece y vivifica a todos los miembros (Ef 4,3) ${ }^{106}$; unidad de los únicos mismos sacramentos (Ef 4,5) ${ }^{107}$; unidad de la esperanza y de la caridad: permiten estas virtudes la elevación a los dones celestiales, así como la unión y la vivificación (Ef 4,4 y Flp 2,2) ${ }^{108}$; y unidad del fin: la visión de Dios (Mt 20,1-16) ${ }^{109}$.

\section{Eadem}

¿Cuándo nació la Iglesia de Cristo? Como la Iglesia se llama de Cristo, ¿es lógico suponer que su inicio tendría lugar tras su llegada? Aragón refiere cómo fue ésta la opinión de algunos herejes. Decían que la Iglesia comenzó tras la pasión de Cristo. Por eso, añadió inmediatamente el agustino que tal opinión de los herejes conducía a sostener que la Iglesia de los padres no era la única y verdadera Iglesia. No sería la misma Iglesia ${ }^{110}$. Los católicos acostumbran a poner el origen de la Iglesia al principio; pero no mantinen la unanimidad a la hora de señalar el momento exacto. Unos sostienen que se ini-

101. Cf. nota 50

102. Cf. nota 51 .

103. Cf. nota 40 .

104. Cf. nota 41.

105. Cf. nota 42.

106. Cf. nota 43 .

107. Cf. nota 44 .

108. Cf. nota 45 .

109. Cf. nota 46 .

110. Cf. nota 52 . 
ció la misma con la creación de los ángeles ${ }^{111}$. Otros colocan su comienzo en la aparición de Adán y de Eva antes de haber incurrido en pecado ${ }^{112}$.

Todas estas opiniones se presentan con sus respectivos argumentos. Quienes dicen que la Iglesia se inició en Cristo se fijan ante todo en la Sagrada Escritura. El evangelio de San Mateo $(16,18)$ habla con toda claridad de que la Iglesia de Cristo se levanta sobre el fundamento: San Pedro. Se sirven también del razonamiento. Así dicen que la Iglesia surge gracias a la fe y ésta no existía antes de la venida de Cristo. Fundamentan su aseveración en los testimonios de la carta a los Gálatas $(3,24-25)$ y de la carta a los Hebreos $(11,13)$. Cuentan incluso con el apoyo que les suministraría San Agustín en algunos de sus comentarios sobre la Sagrada Escritura ${ }^{113}$. Quienes colocan el inicio de la Iglesia en la creación de los ángeles se fijan de modo principal en diversos testimonios de los santos, según los cuales gozaron los ángeles desde el principio de la posesión de la fe y de la gracia, así como recuerdan que la multitud de los ángeles era la esposa de Dios antes de convocar la Iglesia de los hombres ${ }^{114}$. Los que sostienen que la Iglesia comenzó con Adán y Eva indicarán por su parte cómo la primera pareja humana tuvo fe en la encarnación antes de incurrir en pecado. A ello se debe que fueran verdaderamente miembros del cuerpo de Cristo: la Iglesia ${ }^{115}$.

¿No es la fe una realidad interior? Ciertamente, nadie puede estar seguro de la fe de otra persona. ¿Se requiere únicamente la fe para formar parte de la Iglesia de Cristo o se necesita poseer algo más? Si se requiriera sólo la fe, se estaría ante una Iglesia del todo invisible. La Iglesia es visible también. Si se supone entonces que basta la existencia de la fe para que uno sea considerado de la Iglesia ${ }^{116}$, deberá reconocerse inmeditamente también que la misma comenzó con la creación de los ángeles ${ }^{117}$. Pero no se habla aquí de una Iglesia del todo invisible. Hace falta algo más que la posesión de la fe. El creyente debe hacer además profesión exterior de su fe con alguna señal visible. Es preciso que la confiese ante los demás. Así suelen referirse comúnmente a la Iglesia los doctores. De esta manera es como se hablará aquí. Salta a la vista que se está poniendo el acento exclusivamente en la Iglesia visible ${ }^{118}$.

111. Cf. nota 54.

112. Cf. nota 55 .

113. Cf. nota 53 .

114. Cf. nota 54.

115. Cf. nota 55 .

116. Cf. nota 56

117. Cf. nota 57

118. Cf. nota 56 
La existencia de la Iglesia visible comenzó antes de la venida de Cristo en cuanto los hombres no esperaron a tener noticia de su llegada para exteriorizar su fe. El antiguo testamento suministra suficientes testimonios de cómo, antes de la venida de Cristo, ya se confesaba exteriormente la fe ${ }^{119}$. En modo alguno se oponen a esta conclusión los testimonios aludidos con anterioridad de las cartas a los Gálatas $(3,24-25)$ y a los Hebreos $(11,13)$ sobre la ausencia de la fe antes de Cristo. La enviada a los Gálatas habla de cómo el justo vive de la fe $(3,12)$ y el capítulo 11 de la carta a los Hebreos muestra largamente que todos los salvados lo fueron gracias a la fe. El texto de la carta a los Gálatas puede significar también que no estaba la fe revelada antes de la venida de Cristo. La misma se encontraba hasta entonces oculta. Asimismo, puede significar que lo que se creía en el antiguo testamento como futuro, se cree después como cumplido. El mismo texto de la carta a los Hebreos $(11,13)$ indica a las claras que quienes murieron tuvieron a la fe como asociada y compañera. Dejaron ciertamente este mundo unidos a la fe ${ }^{120}$.

¿Está entonces Aragón plenamente de acuerdo con el inicio de la Iglesia en Adán y Eva? Si ésta hubiera comenzado en Adán, ¿podría sostenerse que la misma permaneció idéntica sin interrupción alguna? Debería reconocerse ciertamente que, después del pecado de Adán, hubo un tiempo en el que no habría existido la Iglesia. La misma habría desaparecido. ¿A qué se debe esta aseveración? Al pecar, Adán y Eva conservarían la fe; pero habrían perdido entonces la caridad. Sin ésta no existe la Iglesia. Para evitar este inconveniente, es por lo que debe decirse que la Iglesia comenzó en Abel. Esta visión se corresponde además con la carta a los Hebreos $(11,4)$. El autor de la misma coloca a Abel como el primero de los pertenecientes a la Iglesia ${ }^{121}$. Aragón se decanta a favor de fijar el inicio de la Iglesia en quienes, además de poseer la fe, la confiesan exteriormente mediante algún signo visible. Por eso, dice que la misma se inició en el justo Abel. Así hablan diversos comentarios de San Agustín; pero lo más decisivo en esta cuestión es que se trata de algo aceptable desde la razón en cuanto se está haciendo referencia a la Iglesia visible. La fe ha de demostrarse exteriormente. El capítulo tercero del Génesis indica a Abel como el primero que confesó la fe de modo visible ${ }^{122}$.

¿Acaso no confesó ambién exteriormente su fe Adán? ¿No dijo el Maestro que fue el padre quien enseñó a los hijos a ofrecer primicias y diezmos? ¿Acaso no murió Abel quedando la fe en Adán y en Eva? ${ }^{123}$. Aragón dará

119. Cf. nota 58 .

120. Cf. nota 59 .

121. Cf. nota 61 .

122. Cf. nota 60 .

123. Cf. nota 62 . 
respuesta a estos argumentos y dirá cómo no se lee en el pasaje citado del Maestro que ofreciera Adán sacrificio alguno exterior. No hay inconveniente alguno en conceder que Adán conservara la fe tras su pecado; pero es algo que no basta por sí solo para poner en él el comienzo de la Iglesia visible. Fue además conveniente que no se pueda leer que Adán ofreció sacrificios. Como dice Santo Tomás, el origen de la santificación no era oportuno que comenzara en quien había tenido inicio el pecado ${ }^{124}$. Insistirá Aragón en que no basta tener fe para hablar del inicio a la Iglesia en cuanto se habla aquí de la visible. Por otra parte, pretender decir que la Iglesia, tras la muerte de Abel, perseveró únicamente en Adán y Eva como creyentes significa dar por supuesto que los mismos no habían tenido para entonces otros hijos. No se considera argumento sólido decir que tales hijos nuevos no existieron por no aparecer mencionados en la Sagrada Escritura ${ }^{125}$. ¿Qué ocurre entonces si se dice que, antes de incurrir en pecado, tuvo Adán verdadera fe y verdadera gracia? Es algo que no hace al caso presente. Que las poseyera es una gran verdad; pero no debe olvidarse que se está hablando en este lugar de la Iglesia visible y, de la misma, se forma parte por la profesión de la fe mediante un signo exterior ${ }^{126}$.

Aragón sostiene que la Iglesia actual y la que existió antes de la pasión de Cristo es una e idéntica. Ello se debe ante todo a que los justos existentes en la una y en la otra poseyeron la única y la misma fe, lo cual hace que pertenezcan a la misma Iglesia única en cuanto ésta se constituye gracias a la fe. Así lo muestra además la carta segunda de San Pablo a los Corintios $(3,12-18)^{127}$. Es la Iglesia comenzada en Abel la que ha de durar hasta el fin del mundo. Es algo afirmado también por San Agustín cuando dice que Dios la fundó para siempre. Se prueba también desde la Sagrada Escritura: Is 9,7; Lc 1,32-33; Os 2,19 y Mt $16,18{ }^{128}$. ¿Ha fallado alguna vez la fe en la Iglesia desde su inicio? Aragón hablará de que tal cosa nunca ha sucedido. Dirá asimismo que es algo que nunca llegará a suceder. El no haber desfallecido en el pasado es algo afirmado por San Agustín. Que no ha de desfallecer en el futuro se prueba en cuanto, si se diera tal caso, habría que deducir que Cristo no habría permanecido siempre en la Iglesia. A todas luces es absurdo realizar semejante afirmación en cuanto Él estará junto a la Iglesia hasta la consumación del mundo. En

124. Cf. nota 63.

125. Cf. nota 64 .

126. Cf. nota 65 .

127. Cf. nota 66 .

128. Cf. nota 67 . 
la Iglesia hubo siempre fe verdadera, caridad verdadera y verdadero uso de los sacramentos. Si no están estas tres realidades, no hay Iglesia ${ }^{129}$.

Si la Iglesia posterior a la venida de Cristo es la misma que la que existió con anterioridad, ¿dónde se halla la superioridad del nuevo sobre el antiguo testamento? Aragón reconoce que la única Iglesia de Cristo fue en un tiempo más una que en otro. La Iglesia anterior a Cristo no poseía un solo vicario. El presidente de los judíos no presidía a los gentiles ${ }^{130}$. Además, la Iglesia actual cuenta con unos sacramentos que son los únicos y los mismos, así como acepta una sola ley. La existente antes de la venida de Cristo no poseía los mismos sacramentos ni la misma ley. Mientras los judíos se servían de la ley escrita y de los sacramentos mosaicos, los gentiles se servían de la ley natural y de los sacramentos establecidos en ella. Todo ello lleva al reconocimiento de que la Iglesia posterior a Cristo es más una que la que existió con anterioridad a su venida ${ }^{131}$. De la Iglesia cabe hablar de forma estricta y muy estricta. En la primera de ellas, se hace referencia a la congregación de creyentes que profesan su fe mediante algún signo visible. De la segunda manera, se apunta a la que hace profesión de ella por los signos y sacramentos instituidos por Cristo ${ }^{132}$.

\section{Vera}

La Iglesia es una ciertamente y es visible; pero, ¿no existe una Iglesia verdadera y otra falsa? ¿No se ha de distinguir la de Cristo de la congregación de Satanás? Los herejes (luteranos) entienden que la suya es la verdadera Iglesia de Cristo santa y católica. Niegan rotundamente que lo sea la de los católicos ${ }^{133}$. ¿Se ha quedado la Iglesia de los católicos en las obras exteriores y no ha captado que lo importante es la fe? ¿Se ha quedado en sinagoga sin pasar a convertirse en la Iglesia? Se diferencian a las claras iglesia y sinagoga. Aunque ésta sea palabra griega y signifique reunión como la Iglesia, la misma es reservada en los Libros Sagrados para designar cualquier clase de reunión. Se aplica incluso a las reses cuando están juntas. Iglesia se reserva en todo momento a la reunión de personas. Son éstas las que pueden ser convocadas ${ }^{134}$. Aunque se da el nombre de iglesia correctamente al lugar donde se realiza la congregación de las perso-

129. Cf. nota 68 .

130. Cf. nota 47.

131. Cf. nota 48 .

132. Cf. nota 56.

133. Cf. nota 31.

134. Cf. nola 13. 
nas ${ }^{135}$, se quiere indicar frecuentemente bajo el término de Iglesia la multitud de creyentes que concuerda en la fe y en el culto del único Dios en orden a alcanzar el fin sobrenatural. Aunque forman parte de la Iglesia aquéllos que han alcanzado la gloria del cielo, se restringe en esta definición el término de Iglesia para designar sólo a los que caminan por este mundo hacia la salvación. Aquí se habla sólo de la militante ${ }^{136}$.

Es lógico preguntar si la Iglesia militante es la comunidad de los buenos y si está formada exclusivamente de personas en gracia de Dios. Esta pregunta no es ociosa. Los luteranos conciben siempre la fe unida a la caridad. Al lado de la fe ha de estar en todo momento la gracia de Dios. Según ellos, hablar de una única Iglesia de creyentes será decir que está formada únicamente por justos y santos. Los católicos discrepan de estos herejes. No unen necesariamente la fe y la caridad. En la Iglesia militante hay pecadores también. Así concebida por los católicos, ¿puede ser designada la Iglesia de los católicos en razón de sus pecados como la de Satanás?

Aragón distingue en este punto entre un concepto amplísimo de Iglesia y un concepto más restringido. En toda su amplitud, se designa con el nombre de Iglesia cualquier reunión de personas. No se distingue entonces si son las mismas buenas o malas, fieles o infieles. A esa amplísima reunión es a la que se refiere el Salmo $(25,5)$ al hablar del odio hacia la Iglesia de los malvados. De todas formas, los sagrados escritores suelen emplear esta expresión de Iglesia de Satanás, o ciudad de Babilonia, en referencia a la congregación de personas que coexiste al lado de la Iglesia de Cristo. Nació tal Iglesia de Satanás al mismo tiempo que ella, creció juntamente con ella y perseverará también con ella hasta el fin del mundo ${ }^{137}$.

La verdadera Iglesia de Cristo ha permanecido siempre unida a la fe verdadera de Cristo y al uso auténtico de los sacramentos. Católicos y herejes convienen además en que la Iglesia verdadera no puede equivocarse en materia de $\mathrm{fe}^{138}$. ¿Es fácil llegar desde la verdadera doctrina a reconocer con certeza cuál de las dos es la auténtica Iglesia de Cristo? Si se investigara dónde se da la verdadera doctrina y el auténtico uso de los sacramentos, no se obtendrá al final una solución clara. Ello se debe a que se trata de un signo oscuro. Precisamente, ahí es donde reside la gran discusión entre católicos y herejes. Lo que se trata de decidir es saber cuál es la verdadera fe y el auténtico uso de los sacramentos. Para lograr este objetivo se hace preciso echar mano de

135. Cf. nota 14.

136. Cf. nota 16.

137. Cf. nota 15 .

138. Cf. nota 31 . 
otros signos. Sólo así será posible saber cuál es la verdadera Iglesia de Cristo y cuál es la falsa ${ }^{139}$.

Se llega a distinguir la verdadera Iglesia de la falsa en primer lugar gracias a la concorde y unánime confesión de la fe cristiana entregada por los Apóstoles de palabra y por escrito, tal y como fue entendida desde el principio por los santos padres así como por los Sumos Pontífices y los concilios. Será entonces la Iglesia verdadera aquélla que reúna las condiciones indicadas en semejante comprensión. Según Aragón, no cabe duda de quiénes son los que poseen la doctrina concorde con el sentir de los padres y de los concilios. Asimismo, dirá que es fácil reconocer cuáles son las personas seguidoras de la autoridad de los santos y de los concilios en la inteligencia de las Sagradas Escritura frente a las que persiguen inteligencias nuevas ${ }^{140}$.

No se entiende con claridad lo que dicen los Libros Sagrados. Obtener claridad en esta cuestión implica superar multitud de obstáculos. Ante la Sagrada Escritura, cada cual afirma su propia inteligencia. Es precisamente entonces coherente con la razón aceptar por la fe como muy verdadera y muy cierta entre todas las posibles interpretaciones la aprobada desde el principio de la Iglesia por tantos santos padres y concilios. Es asimismo muy coherente no aceptar la encontrada por unos hombres que, además de pocos, llevan una conducta escandalosa. Además de ser esta opinión de San Agustín, es algo que guarda armonía con la Sagrada Escritura: Deut 32,7; Job 8,8; Sal 43,2 y Prov 3,5. El libro del Eclesiástico $(8,11)$ dice a este respecto que no se deben despreciar las opiniones de los ancianos ${ }^{141}$. La verdadera Iglesia de Cristo es la congregación de los que creen en Cristo; pero sus componentes, además de coincidir en la auténtica fe y el verdadero uso de los sacramentos, aceptan también la doctrina que los santos padres y los concilios dedujeron unánimemente desde las Sagradas Escrituras y desde la tradición antigua ${ }^{142}$. ¿En qué comunidad concreta se cumplen todas estas condiciones? ¿Se halla realizado esto de verdad en la Iglesia de los herejes alemanes o en la que obedece al Sumo Pontífice? ${ }^{143}$.

Ha de tenerse como de fe que la verdadera Iglesia de Cristo regida por el Espíritu Santo, fuera de la cual no hay salvación, es la congregación de los fieles que reconoce y sigue al Pontífice de Roma como sucesor de Pedro y cabeza vicaria de Cristo. Ésa no es otra que la congregación que, en el año 1584,

139. Cf. nota 32 .

140. Cf. nota 33.

141. Cf. nota 34 .

142. Cf. nota 35.

143. Cf. nota 69. 
servía bajo Gregorio XIII: el Sumo Pontífice. Mantiene la misma sobre la fe y los sacramentos lo existente en las Sagradas Escrituras como lo entendieron los santos padres y los concilios ${ }^{144}$. La verdadera Iglesia permanece firme, invulnerable e inconmobible contra todas las trombas y tempestades del mundo. Esto se cumple ciertamente en la de Roma y no se verifica en la de los herejes de Alemania. Mantiene la misma fe tenida al principio. La de los herejes ha cambiado con mucha frecuencia la doctrina y ha llegado a extinguirla incluso. La única firme y estable es entonces la Iglesia de Roma ${ }^{145}$. Cuando se pone la vista en la santidad y en la perfección inherente a la Iglesia de Cristo por su modo de vida santo y honesto, se obtiene la misma conclusión. Se hallan bien instituidos en la Iglesia de Roma tanto la religión para con Dios como el culto divino. Dispone de templos, utiliza ministros y organiza ceremonias convenientes. Los herejes de Alemania carecen en cambio de templos y de sacerdotes No tienen además motivo para rezar y para alabar a Dios ${ }^{146}$.

A todo ello se añade la vida sobria que observan los que obedecen al Pontífice de Roma mediante ayunos y elección de alimentos. Se da en ella asimismo el mayor de los cultos a la justicia para con el prójimo. Se enseña que hay obras meritorias en orden a alcanzar la vida eterna, así como se dan otras que llevan al suplicio eterno. Los herejes de Alemania sostienen al respecto que de nada sirven las obras justas o injustas en orden a merecer o desmerecer ante Dios. Entonces, si la Iglesia de Roma es más santa que la de los alemanes, habrá que reconocer también que es la verdadera ${ }^{147}$. Cae de su peso también que la Iglesia de Cristo es católica o universal. La misma se encuentra extendida por el orbe entero. Abarca todos los lugares, tiempos y naciones. Pero la Iglesia de los luteranos no cuenta más que con cuarenta años de vida. Se halla colocada además en un rincón de la tierra. Muy distinto es lo que ocurre al respecto con la que obedece al Pontífice de Roma ${ }^{148}$.

La Iglesia de Roma sigue la doctrina de los Apóstoles. No se limita a aceptar únicamente lo que consta que ellos transmitieron por escrito. También recibe lo entregado de viva voz. Esta actitud es coherente con lo expresado en la Sagrada Escritura. La de Roma se atiene entonces de verdad a la doctrina de los Doce. Esto no acaece en la de los herejes alemanes ${ }^{149}$.

144. Cf. nota 70 .

145. Cf. nota 71 .

146. Cf. nota 72 .

147. Cf. nota 73 .

148. Cf. nota 74 .

149. Cf. nota 75 . 
Aragón se fija asimismo en la sucesión de los Apóstoles. La Iglesia ha de tener como autoridad a los que suceden en la cátedra a los Doce, así como debe confesar la misma fe que ellos confesaron. Desgraciadamente, no acaece esto en la Iglesia de los herejes germanos ${ }^{150}$. ¿Se halla acaso la Iglesia de éstos bien ordenada? ¿Cuenta con prelados y súbditos? Acostumbran los herejes luteranos a decir que todos, hasta las mujeres, son sacerdotes y jueces. Consecuentemente, sólo la Iglesia de Roma es la verdadera ${ }^{151}$.

¿Qué debe decirse ahora de la afirmación luterana de que ellos son la verdadera Iglesia de Cristo y que la seguidora del Pontífice de Roma es el grupito del Anticristo? Es éste un estribillo repetido por cualquier reunión de herejes. Suelen acostumbrar éstos a llamarse a sí mismos cristianos. Juzgan y confiesan que la suya es la Iglesia católica. Lo hacían así Novaciano y Donato en la antigüedad. La misma actitud tomaron en la Edad Media los pobres de Lyón. A todos ellos les imitaron con posterioridad los picardos ${ }^{152}$.

\section{CONCLUSIÓN}

El moderno tratado sobre la Iglesia empezó a gestarse en la Salamanca del siglo XVI con motivo del comentario sobre la fe según el texto de la Suma Teológica de Santo Tomás de Aquino ${ }^{153}$. A lo largo de los siglos precedentes se había aceptado unánimente entre los bautizados que la fe obligatoria es aquella que, como tal, propone la Iglesia. Diversas circunstancias obligarán a los teólogos salmantinos del siglo XVI a no tratar sobre la fe sin mencionar al mismo tiempo a la Iglesia. Es ésta una novedad exigida por los tiempos nuevos. Ello se debe ante todo a la aparición en Alemania de la Reforma Luterana y a su extensión progresiva por Europa. Cuando Aragón edita en 1584 sus comentarios a la Secunda Secundae del Doctor Angélico, la discusión entre católicos y luteranos sobre la Iglesia ha dado frutos palpables. Se reflejan los mismos en los comentarios del agustino. Reconoce éste a las claras lo que une a unos y a otros. Existe unanimidad en que la Iglesia de Cristo arranca de cuatro causas y en que se distingue también por cuatro notas: unidad, santidad, catolicidad y apostolicidad. Indica además cómo, a pesar de semejantes coincidencias, se dan discrepancias de enorme relevancia entre unos y otros respecto a la Iglesia de Cristo.

150. Cf. nota 76 .

151. Cf. nota 77 .

152. Cf. nota 69.

153. Cf. nota 10 . 
Luteranos y católicos conciben la fe como fundamental para que pueda hablarse de Iglesia de Cristo. Unos y otros están de acuerdo en que los infieles y los herejes no se hallan incluidos dentro de ella. Se coincide también en que la fe es una realidad sobrenatural e interior. Cada persona puede estar cierta de su propia fe; pero es imposible que uno esté seguro de que la tienen también los demás. Siempre cabe la mentira y el engaño de por medio. Aquí es donde empieza a aparecer la discrepancia entre católicos y luteranos. Éstos, al concebir la Iglesia como la congregación de los creyentes, proclamarán incluso que la de Cristo está formada sólo por las personas interiores. Dirán en consecuencia que la Iglesia es del todo interior e invisible. Opondrán asimismo el viejo al nuevo testamento. Sugerirán de alguna manera que fue exterior y visible la que se dio antes de la venida de Cristo; pero que la Iglesia perfecta y definitiva es la existente tras la venida de Cristo. A la misma se la imaginan de naturaleza totalmente interior e invisible. La Iglesia de los católicos se presentará a sus ojos nada más que como una continuación de la del antiguo testamento. No habría superado la misma el estadio de la ley antigua. Hasta se permitirán insinuar que, a la de los católicos, se le debería llamar propiamente con el nombre de sinagoga. No cabe duda que esta concepción, según la cual la Iglesia existió sólo tras la venida de Cristo, concretamente tras su pasión, facilitaba enormemente las cosas a la hora de explicar la unidad de la Iglesia. Se evitaba con ello tener que probar cómo la anterior y la posterior a Cristo forman en realidad una sola idéntica Iglesia.

En la mentalidad de los herejes luteranos, la fe se halla acompañada siempre de la caridad. A sus ojos resulta impensable que la una se halle separada de la otra. Esto repercute en la concepción de la Iglesia. Decir que se forma ésta exclusivamente de creyentes significa afirmar al mismo tiempo que consta sólo de justos y santos. Los pecadores quedarán consecuentemente excluidos como miembros de la Iglesia de Cristo. Es cierto que los católicos admiten la existencia de justos y de santos en ella. Es más, si la fe es necesaria para formar parte de la Iglesia, de la misma manera debe decirse que ha habido, hay y habrá en todo momento verdadera santidad en ella. Cosa diferente es sostener también que todos sus miembros sean santos. De todas maneras, es verdad que, al final, sólo los santos han de formar parte de la Iglesia triunfante del cielo. Se comprende ahora bastante fácilmente por qué se esfuerzan los herejes en proclamar que la suya es la Iglesia verdadera. Se la imaginan formada por solo santos, los cuales están unidos a la cabeza: Cristo, y participan de su vida. No es extraño entonces en modo alguno que se refieran a ella como la Iglesia de Cristo. También se llega a comprender desde esta perspectiva por qué no se recatan tales herejes de llamar a la 
Iglesia de los católicos la de Satanás. No se olvide que ésta admite en su seno, mientras camina por esta vida, a los creyentes aunque sean pecadores.

La Iglesia de Cristo es invisible; pero es también visible. De la Iglesia invisible se forma parte por la sola fe. Este hecho posibilita la salvación antes de la venida de Cristo. No se olvide a este respecto que la Iglesia es aquel lugar, fụera del cual no existe salvación alguna. Hubo verdadera fe en la ley natural y en la ley escrita. Ciertamente, se da auténtica Iglesia donde existe fe. Así se explica que los catecúmenos puedan salvarse y pertenezcan a la Iglesia de Cristo en cuanto a mérito. Además, no hay inconveniente alguno en reconocer que los ángeles formaran parte de la Iglesia desde el mismo momento de su creación y que Adán estuviera en la Iglesia antes del pecado. La razón es muy simple. Ello se debía a que tenían los ángeles y Adán verdadera fe. Ahora bien, ¿la Iglesia se reduce sin más a la fe? ¿Es del todo invisible? A la misma se le puede ciertamente ver. La fe necesita también ser profesada exterior y visiblemente. Por eso, el concepto de Iglesia de Cristo se puede restringir todavía más. Se dirá desde esta concepción más restringida que los catecúmenos no forman parte de la Iglesia visible, así como que no se les cuenta en ella numéricamente. Ya no se puede decir que los ángeles y Adán pertenecen a la Iglesia visible. Su inicio es preciso ponerlo en el justo Abel. Si el mismo se colocara en Adán, sería preciso probar que éste confesó exteriormente su fe. Se toparían los teólogos además con un problema prácticamente irresoluble. Sería preciso admitir que hubo un tiempo al menos, mientras Adán y Eva permanecían en el pecado, en el que la caridad habría desaparecido por completo de la Iglesia. No se podría sostener la verdad manifiesta de que, además de no desfallecer en la fe, la Iglesia no se vio, ni se verá, privada en momento alguno de la presencia de la caridad.

¿Cabe la posibilidad de colocar el principio de la Iglesia de Cristo después de la pasión? ${ }^{154}$. Como se ha expuesto ya, ello supondría negar que se diera también la única y verdadera Iglesia en la ley natural y en la ley antigua. lo cual no se corresponde con los testimonios de la Sagrada Escritura y de los santos padres. Todos afirman con total rotundidad que hubo fe verdadera $y$ confesión visible de la misma antes de Cristo. De todas formas, es innegable que, con tal venida, la Iglesia no adquiere sustancia nueva de fe. Simplemente, lo que estaba antes oculto queda ahora revelado y manifestado tras la venida de Cristo. Puede decirse entonces que, siendo la misma la fe existente en la ley natural y antigua, es más una y más perfecta después de su llegada.

154. Aragón se hace eco de cómo hubo autores que llegaron a proponer cómo la Iglesia quedó reducida a su más mínima extensión en la Virgen María durante el triduo de la pasión de Cristo en cuanto perdieron todos los Apóstoles la fe y la caridad quedando éstas únicamente en la Madre de Dios. 
Lo mismo ocurre con la Iglesia. Esta mayor unidad surge además de la cabeza visible existente en la Iglesia posterior a Cristo. Además de encontrarse toda ella sometida al único príncipe: Cristo, cuenta además Éste en ella con un único vicario: el Sumo Pontífice. Era algo de lo que carecía la Iglesia antes de la llegada de Cristo. El Sumo Sacerdote se imponía entonces a los judíos; pero no era reconocido como tal por los gentiles. Su autoridad no era universal en la única Iglesia existente. Las razones aducidas para admitir tantas Iglesias de Cristo como reinos no se sostienen. Su objetivo es debilitar claramente la autoridad suprema en la Iglesia. Las de Galacia y de Asia eran Iglesias particulares. Los catecúmenos se han hallado siempre en cuanto a mérito dentro de la única Iglesia de Cristo. Los obispos, pese a su independencia unos de otros, se encuentran sometidos a la autoridad suprema de Roma.

Si la Iglesia de Cristo es una, saltará a la vista irremediablemente que no pueden serlo a la vez la de los luteranos y la de los católicos. Sus discrepancias son realmente de relive. Con lógica dirán entonces los luteranos que ellos son la verdadera y que no lo es la que obedece al Sumo Pontífice de Roma. Otra cosa es que tengan razón. ¿Es verdad lo sostenido por los herejes? ¿Es su Iglesia la verdadera de Cristo? Las cuatro notas o propiedades de la Iglesia son aprovechadas en este momento por Aragón para verificar si las mismas se cumplen en la de los luteranos o en la de los católicos. No cabe duda que el resultado inclina claramente la balanza a favor de que la Iglesia de los católicos es la verdadera. De todas formas, Aragón señalará que el punto decisivo para conocer con certeza cuál es la verdadera Iglesia de Cristo entre las que presumen de serlo no es otro que la recepción de la doctrina de los Apóstoles en su integridad. No basta recibirla en cuanto escrita. Está a la vista cómo la intelección de los Libros Sagrados termina reflejando siempre el pensamiento de cada uno de los que la interpretan particularmente. Es preciso huir además de interpretaciones nuevas. Se ha de aceptar la doctrina de los Apóstoles en su totalidad: tanto lo que escribieron como lo que transmitieron de viva voz. Además, no cabe más remedio que recibir la intelección de la Sagrada Escritura como la han venido presentando unánimemente los santos padres y los concilios. No cabe duda alguna que esto es lo que hacía la Iglesia que obedecía en 1584 al papa Gregorio XIII. Cae de su peso además que ésa es la única y misma Iglesia verdadera de Cristo. 